\title{
Espaço, materiais e forma no teatro musical pós-1960: composição e dramaturgia em obras de Mendes, Kagel e Aperghis $^{1}$
}

\author{
Space, materials, and form in the post-1960 music theater: composition and \\ dramaturgy in works by Mendes, Kagel e Aperghis
}

\author{
Heitor Martins Oliveira \\ Universidade Federal do Tocantins
}

\begin{abstract}
Resumo: O teatro musical pós-1960 integrou as investigações composicionais das vanguardas musicais. Procedeu a uma renovação de perspectivas que abarca sonoridades e técnicas desenvolvidas nos anos 1950 para expandi-las, na direção da exploração de elementos não-sonoros da performance musical. Ao colocar em jogo enção e organização de materiasi elementos de teatralidade, abriu-se a possibilidade de considerar a relação entre composição - invenção e organização de materiais sonoros - e dramaturgia, entendida de maneira ampla, como organização de eventos cênicos. Este ensaio discute três aspectos das abordagens composicionais no limiar música/gesto: a situação de performance musical como espaço cênico; a seleção, invenção e organização de materiais como jogo cênico; estrutura (divisibilidade em partes) e forma (conteúdos e suas continuidades) como encenação. A concretização desses aspectos em obras específicas dos três compositores - Mendes, Kagel e Aperghis - revela a aproximação entre composição e dramaturgia principalmente por meio da aplicação de critérios e procedimentos composicionais musicais aos materiais cênicos; e da construção e deslizamento de sentidos narrativos na performance musical.
\end{abstract}

Palavras-chave: Composição Musical; Teatro Musical; Dramaturgia

\begin{abstract}
The post-1960 music theater integrated the compositional investigations of the musical avant-gardes, proceeding to a renewal of perspectives that included sonorities and techniques developed in the 1950s to expand towards the exploration of non-sonic elements of musical performance. By putting elements of theatricality into play, composers made possible to consider the relationship between composition - invention and organization of sound materials - and dramaturgy, broadly understood as the organization of scenic events.

${ }^{1} \mathrm{O}$ ensaio apresenta material extraído da minha tese de doutorado "Música-como-teatro: uma prática composicional e sua autoanálise" (Oliveira, 2018), pesquisa realizada com apoio de bolsa Capes/Prodoutoral, no Programa de Pós-Graduação da Universidade Federal do Rio Grande do Sul, sob orientação do Prof. Dr. Celso Loureiro Chaves.
\end{abstract}


MUSICA THEORICA Revista da Associação Brasileira de Teoria e Análise Musical 2019, v. 4, n. 1, p. 124-159-Journal of the Brazilian Society for Music Theory and Analysis@ TeMA 2019 - ISSN 2525-5541

This essay discusses three aspects of the compositional approaches on the music/gesture threshold: the musical performance situation as a scenic space; the selection, invention and organization of materials as scenic play; structure (divisibility into parts) and form (contents and their continuities) as staging. The accomplishment of these aspects in specific works of composers - Mendes, Kagel and Aperghis - reveals the approximation between composition and dramaturgy mainly through an application of musical compositional criteria and procedures to scenic materials; and to the construction and sliding of narrative meanings in musical performance.

Keywords: Music Composition; Music Theater; Dramaturgy

\section{Introdução}

Na complexa teia de possibilidades exploradas por compositores desde a década de 1960, encontra-se uma série de interações música/gesto, cuja diversidade dificulta a formulação de uma definição simples ou mesmo a adoção de uma terminologia única. ${ }^{2}$ Trubert (2015) propõe uma efetiva delimitação geral do fenômeno, aberta quanto aos elementos estéticos colocados em jogo e pontual quanto ao contexto histórico:

A partir da segunda metade do século XX, o teatro musical (Musiktheater, em alemão) é um gênero que designa as obras de compositores da jovem geração do pós-guerra, que utilizam como material situações, eventos, elementos extramusicais - o corpo, o gesto, a voz, a cenografia, a iluminação - , concomitantemente ou não a um enredo ou a uma condução dramatúrgica, e no qual o aspecto visual e gestual torna-se um componente essencial ${ }^{3}$ (Trubert 2015, p. 1269; tradução nossa).

\footnotetext{
2 Além dos termos mencionados neste texto, encontram-se ainda, na literatura, termos como músicas de ação (Bosseur; Bosseur 1990), ópera contemporânea e novo teatro musical (Salzman; Dési 2008), música-teatro (Serale 2009), drama épico (Trubert 2015) e teatro musical experimental (Bithell 2016), cada qual justificado por um recorte ou desejo de especificidade e pertinente de alguma maneira à compreensão do campo. A expressão "teatro musical" traduz aqui as expressões correspondentes em inglês (music theater), francês (théâtre musical) e alemão (Musiktheater), que possuem um histórico documentado de aplicação ao repertório aqui abordado (Trubert 2015, p. 1270). Entretanto, em sentido mais geral, essas expressões são tomadas como referência abrangente a diversas vertentes cênico-musicais, incluindo ópera, comédia musical, teatro de revista. Seu uso, neste trabalho, refere-se exclusivamente ao sentido específico do repertório derivado das experimentações iniciadas por compositores da vanguarda nos anos 1960 e de seus desdobramentos nas décadas seguintes, até os dias atuais.

3 "A partir de la seconde moitié du XXe siècle, le théâtre musical (Musiktheater, en allemand) est un genre désignant les oeuvres des compositeurs de la jeune génération d'après-guerre, qui utilisent comme matériau des situations, des événements, des éléments extramusicaux - le corps,
} 
OLIVEIRA, H. M. Espaço, materiais e forma no teatro musical pós-1960: composição e dramaturgia em obras de Mendes, Kagel e Aperghis

A delimitação que o autor propõe refere-se à abordagem criativa e considera obras musicais nas quais aspectos gestuais e visuais revelam-se como inerentes ao pensamento composicional. A abordagem de Trubert tem como objetivo não somente delimitar esse teatro musical - ou mesmo o teatro instrumental ${ }^{4}$ - como gênero, mas compreender seu lugar e sua relevância para os desdobramentos das investigações composicionais da música nova europeia no período pós-1960: “Longe de ser o simples veículo de uma mensagem qualquer, é ao nível mais fundamental da organização da linguagem composicional, da forma e da irrupção do gesto que esse gênero procede da maneira mais radical a uma renovação de perspectivas" ${ }^{\prime 5}$ (Trubert 2015, p. 1294; tradução nossa).

A relação estabelecida entre material musical e material cênico, conforme salienta Trubert (2015), fornece um dos critérios mais relevantes para mapear o terreno do teatro musical pós-1960, permitindo distinguir formas convergentes, fragmentárias e divergentes. Em formas convergentes, há uma simetria estrutural entre as forças musicais e cênicas, que resulta em continuidade dramática e preserva as características essenciais da ópera, ainda que as sonoridades empregadas tenham afinidade com a música criada no período pósguerra. Nas formas fragmentárias, a condução dramatúrgica é implodida pelo contexto crítico, efeitos de distanciamento e teleologia narrativa de cunho épico. Nas formas divergentes, há uma polifonia informacional e os gestos ganham um caráter incidental, interveniente, relacionado à materialização de uma poética composicional (Trubert 2015, p. 1272).

A delimitação de Trubert (2015) destaca a integração da abordagem do material cênico ao trabalho composicional. Nesse contexto, compositores passam

le geste, la voix, la scénographie, la lumière -, concomitamment ou non à une intrigue ou à une conduite dramaturgique, et dont l'aspect visuel et gestuel devient une composante essentielle."

${ }^{4} \mathrm{Na}$ abordagem do autor, a designação teatro instrumental é reservada à obra de Mauricio Kagel (1931-2008). Cinco características ganham evidência e particularizam o teatro instrumental de Kagel: a teatralização da execução instrumental; o tratamento do lugar de execução como cena; o movimento como elemento fundamental do gênero; o músico como instrumento "ideal", por ser ele que realiza os movimentos; a assimilação da execução e dos movimentos à notação, levando em conta a função do público na recepção da peça para elaboração e realização da partitura (Trubert 2015, p. 1289).

5 "Loin d'être le simple véhicule d'un quelconque message, c'est au niveau le plus fondamental de l'organisation du langage compositionnel, de la forme et de l'irruption du geste que ce genre procède de la manière la plus radicale à un renouvellement des perspectives." 
MUSICA THEORICA Revista da Associação Brasileira de Teoria e Análise Musical 2019, v. 4, n. 1, p. 124-159-Journal of the Brazilian Society for Music Theory

a criar também com os aspectos gestuais e visuais da performance musical e com elementos de espetáculos cênicos, tais como figurinos, cenário e iluminação. Esse processo é distinto daquele empregado tradicionalmente na ópera, onde a encenação é construída em uma etapa criativa posterior à composição musical. Em decorrência dessa importante distinção, a dimensão teatral do teatro musical da segunda metade do século XX é constitutiva da abordagem composicional. ${ }^{6}$ Trata-se de composições musicais para serem assistidas tanto quanto ouvidas, instaurando processos cênicos peculiares, aqui analisados em diálogo com a categoria teatralidade, conforme discutido por teóricos das artes cênicas.

A teatralidade aparece como um processo ligado, antes de tudo, às condições de produção do teatro e não ao grau de semelhança ou desvio em relação ao real representado. Nesse sentido, é possível dizer que não há assuntos mais teatrais que outros, imitações mais teatrais que outras, e que a teatralidade tem a ver com o próprio processo de representação (Féral 2015, p. 97).

Do ponto de vista da recepção, uma vez colocada em jogo uma teatralidade, a apresentação (performance musical) passa a ter, quase inevitavelmente, uma dimensão de representação, de mimese, "ainda que fragmentária e intermitente, ainda que relativa ao espírito do espectador que não pode impedir-se de projetá-la, de criá-la" (Danan 2010, p. 119). O compositor depara-se com a dramaturgia, conforme ela passa a ser entendida na criação cênica a partir do século XX:

Estabelecer um dispositivo, um quadro, para que o jogo e o sentido aí se produzam, sob o risco (desejável) de transbordar do quadro. Seria, pois, a dramaturgia esse quadro (e não mais, como ocorreu por muito tempo, imposição, ou proposição de uma leitura)? Sim. Mas ela é também aquilo que ocorre no interior do quadro, o desenrolar do tempo que aí se inscreve, o jogo entre corpos, as palavras trocadas... a peça que se joga, tal como ela foi escrita e tal como é reinventada... (Danan 2010, p. 121).

Nesse sentido, as investigações criativas na interface música/gesto aproximam a composição musical da noção de dramaturgia, por meio da exploração do potencial de teatralidade da performance musical. As reflexões apresentadas neste ensaio buscam compreender como essa aproximação se

\footnotetext{
${ }^{6}$ Remeto também o leitor a dois artigos anteriores nos quais abordei relações entre composição musical e teatralidade (Oliveira 2015; Oliveira 2016).
} 
OLIVEIRA, H. M. Espaço, materiais e forma no teatro musical pós-1960: composição e dramaturgia em obras de Mendes, Kagel e Aperghis

concretiza nas concepções e no trabalho com os materiais musicais e os materiais cênicos.

A seguir apresento análises de aspectos de obras de compositores reconhecidos por sua atuação na fronteira música-teatro. O objetivo é discutir o pensamento composicional desses autores e sua realização em obras específicas, com foco nas questões referentes às possibilidades de representação e narrativa construídas cenicamente no contexto da performance musical. As fontes primárias da pesquisa são partituras e registros audiovisuais das obras, bem como depoimentos dos compositores.

\section{Situação de performance musical como espaço cênico: Santos Football Music (1969), de Gilberto Mendes}

Em Santos Football Music (1969), ${ }^{7}$ há uma teatralização da situação de performance orquestral, a partir da releitura que Gilberto Mendes (1922-2016) realiza de ações, relações e sonoridades implicadas em uma partida de futebol. A ressignificação da sala de concerto como espaço cênico e a inserção do público no roteiro de ações para concretização da performance são os principais interesses composicionais que situam essa peça específica no âmbito das relações entre composição e dramaturgia.

Do ponto de vista do enquadramento teórico, o espaço é uma das condições fundamentais da experiência teatral. Efetivamente, por si só, “a disposição 'teatral' do lugar cênico traz em si certa teatralidade" (Féral 2015, p. 84). A constituição cênica do espaço refere-se à disposição das pessoas e objetos e ao uso eventual de recursos complementares como iluminação e cenografia. $O$ trabalho espacial se desdobra em toda a transposição do texto (roteiro) para o teatral (cena). O sentido das ações apresentadas no decorrer do acontecimento teatral está emoldurado pelas relações estabelecidas e desenvolvidas entre os elementos dispostos no espaço cênico.

No campo da composição musical, as intervenções na disposição espacial promovem implicações sonoras e visuais que, em conjunto, potencializam a dimensão de teatralidade em performances musicais, inclusive na música orquestral. A expansão da área de performance para incluir palco e plateia é a

\footnotetext{
7 Partitura: Mendes (1979). Vídeo: Mendes (2005a), <https://youtu.be/V3bmKryl-cl $>$, acesso em maio de 2019.
} 
MUSICA THEORICA Revista da Associação Brasileira de Teoria e Análise Musical 2019, v. 4, n. 1, p. 124-159-Journal of the Brazilian Society for Music Theory and Analysis @ TeMA 2019 - ISSN 2525-5541

escolha fundante para a construção de uma teatralidade em Santos Football Music. Parto da leitura mais imediata - e coerente com o que se sabe da intenção expressiva e recepção inicial - de que a peça contém um episódio cênico, para uma leitura pessoal, contextualizada na temática selecionada para este texto, que considera a teatralidade como dimensão estética de toda a peça. Essa leitura remete primordialmente às escolhas composicionais de Gilberto Mendes para envolvimento do público.

\subsection{Teatro musical como dado característico da música de vanguarda}

O comentário de Mendes sobre Santos Football Music em seu livro memorial, enumera elementos e revela sua concepção sobre a relação entre música e teatro nesta peça:

Santos Football Music integra, numa só experiência, quase todos os dados mais característicos da música de vanguarda da segunda metade do século - entre os que lhe são mais caros - como o som concreto (em fitas magnéticas, as três locuções esportivas), o som orquestral atonal, sem melodias (um magma sonoro sempre em transformação, sempre diferente), a participação do público na execução da obra (um segundo regente indica por meio de cartazes o que deve ser feito por ele), o teatro musical (os músicos, no final, fazem o simulacro de um jogo de futebol) e um novo grafismo para a notação de toda essa trama contrapontual; à qual ainda se agrega uma charanga no meio do público, que toca ritmos de escola de samba, à maneira do que se ouve num estádio (Mendes 1994, p. 126).

O elemento teatro musical é definido a partir de ações não vinculadas a qualquer dos dispositivos de produção sonora empregados na peça e caracterizado como simulacro. Um pensamento composicional polifônico organiza os diversos elementos, construindo o resultado estético a partir da interrelação de camadas independentes.

O posicionamento de Mendes, sintetizado numa lista de dados característicos da música de vanguarda e na explicitação de uma concepção criativa que aplica métodos de composição e notação desenvolvidos a partir do campo musical a diversos materiais, converge com as conclusões de Trubert (2015) e Rebstock (2012) $)^{8}$ sobre os avanços de compositores da música de concerto

\footnotetext{
8 Proponente da noção de Teatro Composto que abarca diversas abordagens criativas nas quais os criadores expandem o alcance das estratégias composicionais musicais para os elementos teatrais.
} 
OLIVEIRA, H. M. Espaço, materiais e forma no teatro musical pós-1960: composição e dramaturgia em obras de Mendes, Kagel e Aperghis

do século XX na direção da teatralidade. Note-se que, de acordo com as afirmativas de Mendes, esse desenvolvimento paralelo se deu de maneira independente. O compositor afirma desconhecer boa parte da obra de John Cage e Mauricio Kagel (Mendes 1994, p. 109-110) e contextualiza seu teatro musical no diálogo com a poesia concreta e com os demais compositores do Grupo Música Nova (Mendes 1994, p. 72-76; e p. 133).

A maneira como o compositor rememora o desenvolvimento de sua linguagem composicional, alinhando-se ao que denomina música nova a partir da década de 1960, deixa transparecer o impulso de assumir a multisensorialidade da performance musical como elemento relevante dessa tomada de posição estética.

Por um lado, mesmo em peças como Motet em Ré Menor - Beba Coca-Cola (1966), ${ }^{9}$ não classificadas como teatro musical, gestos e imagens integram o espectro dos materiais composicionais, seja pelas implicações visuais das escolhas de fontes sonoras, pela gestualidade das vocalizações resultantes da dessemantização dos textos ou pela indicação deliberada de gestos ou elementos visuais, como a exibição de cartazes. Por outro lado, o compositor considera Santos Football Music como passo fundamental de sua afirmação composicional:

Foi um trabalho altamente experimental, equivalente ao que realizei quando compus nascemorre. ${ }^{10}$ As duas obras são os momentos máximos de meu radicalismo composicional, ao mesmo tempo que os pontos inicial e final, entre 1962 e 1969, do processo de desenvolvimento de uma linguagem musical, a minha linguagem musical, com pretensões de ser inteiramente nova, em termos brasileiros. A minha última invenção mais radical (Mendes 1994, p. 126).

A mútua relevância de elementos gestuais e visuais em diversas peças e da exploração do teatro musical para consolidação de uma linguagem pessoal perpassam o pensamento composicional de Gilberto Mendes. Esse é o sentido em que melhor se compreende a concepção do compositor do teatro musical como dado característico e integrante da (sua) música de vanguarda.

Em Santos Football Music, está presente o recurso composicional da indeterminação, que Mendes também utiliza em outras obras relacionadas à sua exploração do teatro musical. A notação indeterminada proporciona a

\footnotetext{
${ }^{9}$ Vídeo: Mendes (2005b), <https://youtu.be/6DKRtGjIaD4>, acesso em maio de 2019.

10 Obra de 1962-1963 para coro, duas máquinas de escrever e fita magnética.
} 
MUSICA THEORICA Revista da Associação Brasileira de Teoria e Análise Musical 2019, v. 4, n. 1, p. 124-159-Journal of the Brazilian Society for Music Theory and Analysis @ TeMA 2019 - ISSN 2525-5541

delimitação de qualidades de ação gestual/sonora que preenchem durações específicas, como por exemplo, improvisos com sons sustentados (trompas) sobrepostos a vários sons curtos sucessivos (trombones e flautas) por cerca de 16 segundos (Ex. 1). As combinações contrapontísticas e formais desses elementos, emolduradas pela referencialidade das difusões sonoras e das vocalizações de músicos da orquestra (Ex. 2), do público e, ao final, pelo episódio cênico, proporcionam a sustentação temporal e articulação estrutural da peça.

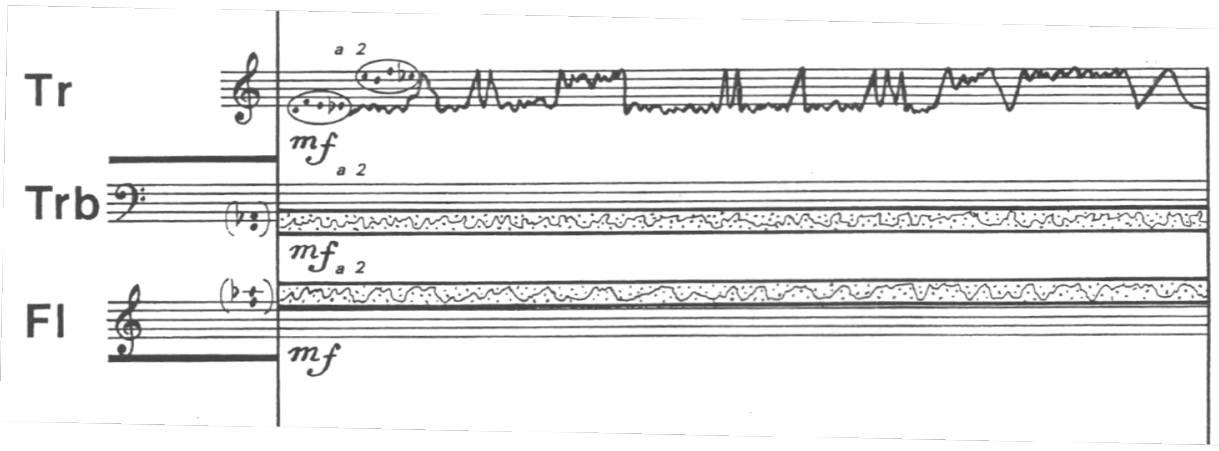

Exemplo 1: partes de trompas, trombones e flautas na página 10 de Santos Football Music, de Mendes

A inserção de gestos, ações e elementos visuais não vinculados diretamente à execução musical, porém integrados à situação de performance, constituem o teatro musical como dado característico e integrante da música de vanguarda, na concepção de Mendes. Este dado é posto em relação com as intenções expressivas, bem como com os recursos e procedimentos de elaboração e organização de materiais explorados pelo compositor, resultando nas possibilidades concretizadas em diversas de suas obras.
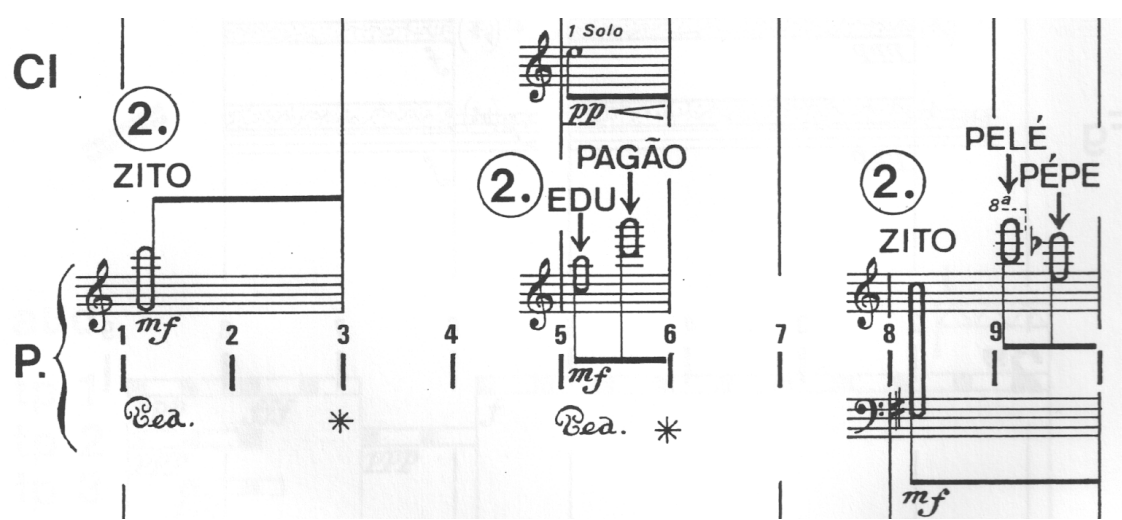

Exemplo 2: detalhe da página 24 da partitura de Santos Football Music, de Mendes, mostrando as indicações para vocalizações a serem realizadas por músicos da orquestra citando nomes de jogadores de futebol 
OLIVEIRA, H. M. Espaço, materiais e forma no teatro musical pós-1960: composição e dramaturgia em obras de Mendes, Kagel e Aperghis

\subsection{Envolvimento do público}

A concepção de teatro musical como dado integrante, camada independente na trama audiovisual da peça, é também evidenciada pela alternativa, sugerida por Mendes nas instruções da partitura, para realização de uma versão de concerto de Santos Football Music:

Uma VERSÃO DE CONCERTO é possível, para esta música, sem a participação do público ouvinte e sem os acontecimentos teatrais. Um coro mixto executa a parte da audiência, sobre o palco. "Tapes" e charanga também sobre o palco. Nesta versão, o regente pode interromper a música em qualquer ponto da página 34, depois de sua metade; e imediatamente retomar a música da última linha da página 35 (7 compassos de pausa e "piano/violino/trombone" em seguida), prolongando a execução do trio final durante o tempo que considerar necessário (Mendes 1979, p. vi).

A versão de concerto é obtida pela remoção dos "acontecimentos teatrais", da participação do público e do uso do espaço da plateia pela "charanga". A "música" permanece viável a partir dos devidos cortes e deslocamento da parte da audiência, "tapes" e charanga para o palco. Ao examinar essas instruções, verifica-se que a participação do público se localiza de fato na intersecção entre duas camadas composicionais. No âmbito sonoro, está vinculada à exploração do som concreto: “O público participa gerando uma espécie de som concreto, ruidoso, ao vivo, pela execução das instruções dos cartazes mostrados por um segundo regente [...]" (Mendes 1994, p. 132). Assim, sob o aspecto sonoro, a participação do público precisa ser substituída por um coro sobre o palco. No âmbito teatral, implica na expansão do espaço de performance e na criação de uma moldura de sentido para ressignificação de toda a situação de performance como representação da partida de futebol. Sob esse aspecto, para que se obtenha a versão de concerto é feita a contenção da expansão do espaço de performance, retida no espaço do palco.

$\mathrm{Na}$ versão de concerto, fica preservado o ímpeto composicional que dá origem à peça e define a intenção expressiva. $\mathrm{O}$ compositor fora estimulado pelo então jornalista Enio Squeff a compor algo relacionado à temática do futebol. Apesar do desinteresse pelo esporte em si, a escuta da transmissão radiofônica de uma partida, principalmente as sonoridades geradas no trabalho vocal de um locutor esportivo, instiga Mendes a iniciar a composição da peça: "Imaginei três irradiações simultâneas, como três instrumentos de um mesmo naipe, na orquestra, soando ora dois, ora um, três, nenhum. Um contraponto a três partes" 
MUSICA THEORICA Revista da Associação Brasileira de Teoria e Análise Musical 2019, v. 4, n. 1, p. 124-159-Journal of the Brazilian Society for Music Theory and Analysis@ TeMA 2019 - ISSN 2525-5541

(Mendes 1994, p. 126). Mendes recompõe sonoridades geradas a partir do contexto da partida de futebol - tanto as do próprio estádio, quanto das transmissões radiofônicas do evento -, organizando-as a partir de recursos composicionais e integrando-as a sonoridades instrumentais da orquestra. Está aí sintetizada a proposta musical que dá sustentação à versão de concerto.

A versão integral, por sua vez, acrescenta a dimensão de teatralidade a partir de um trabalho sobre os sentidos da disposição espacial dos envolvidos na performance. Na sala de concerto, a relação palco-plateia implica na separação entre o espaço de performance e o espaço de fruição. Traz consigo uma série de convenções sobre o tipo de atitude de atenção passiva a ser adotada pelo público, vedado de interferir na performance ou mesmo perturbá-la com sons ou ações espontâneas. No estádio, a relação campo-arquibancada envolve a expectativa de interação e, como nos clichês dos comentários esportivos, a torcida faz parte do espetáculo. Produz ruídos e reage, em tempo real, ao que acontece dentro do campo.

O envolvimento do público na performance, desde o espaço físico da plateia, subverte o sentido da relação de frontalidade na performance musical em salas de concerto. A experiência de teatralidade construída em Santos Football Music consiste em ver de dentro, como se estivesse vendo de fora, uma dimensão teatral da performance que representa a relação palco-plateia como campoarquibancada. Note-se que, com os modos de interação previamente roteirizados e ensaiados, trata-se mesmo de representação e não de transposição de convenções de uma a outra situação. A plateia do concerto não ganha a liberdade de ação que possui a torcida.

Duas outras escolhas composicionais estão relacionadas a essa representação. Primeira, o posicionamento da "charanga" também na plateia, complementando a ressignificação desse espaço como arquibancada. Segunda, a inserção do público no modo de envolvimento na performance ao qual também estão submetidos os músicos, por meio da leitura de uma notação indeterminada. 
OLIVEIRA, H. M. Espaço, materiais e forma no teatro musical pós-1960: composição e dramaturgia em obras de Mendes, Kagel e Aperghis
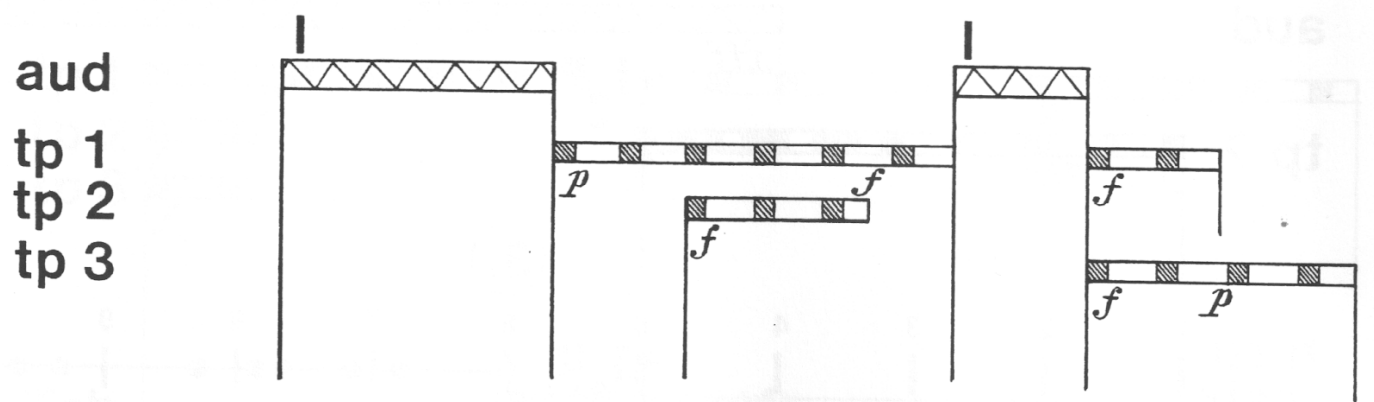

Exemplo 3: reprodução parcial da página 22 da partitura de Santos Football Music, de Mendes, mostrando a notação das intervenções sonoras do público e sua relação com a difusão sonora das fitas magnéticas

A notação usada para orientar o público é constituída de cartazes identificados com as letras A a I, contendo instruções sintéticas para ações sonoras: cantar motivos musicais com a palavra Santos, cantar vogais, falar lentamente em voz baixa, protestar em voz alta, falar "mais um" em voz alta, sustentar som sibilante, sustentar som nasal, gritar a palavra gol e fazer ruídos diversos. Ao longo da partitura, as intervenções do público são indicadas por meio das letras, com a duração de cada ação sonora sendo indicada graficamente, a partir do alinhamento vertical com as demais partes (Ex. 3). De acordo com as instruções para performance presentes na partitura, “O PÚBLICO PARTICIPA SEMPRE INDEPENDENTEMENTE DO TEMPO ORQUESTRAL, EM SEU PRÓPRIO TEMPO”' (Mendes 1979, p. II, caixa alta no original). Ou seja, há uma simultaneidade de camadas sonoras, sem necessidade de sincronia métrica.

Entretanto, o envolvimento do público tem implicações ainda mais abrangentes para a concepção da peça. A descrição do compositor é a seguinte:

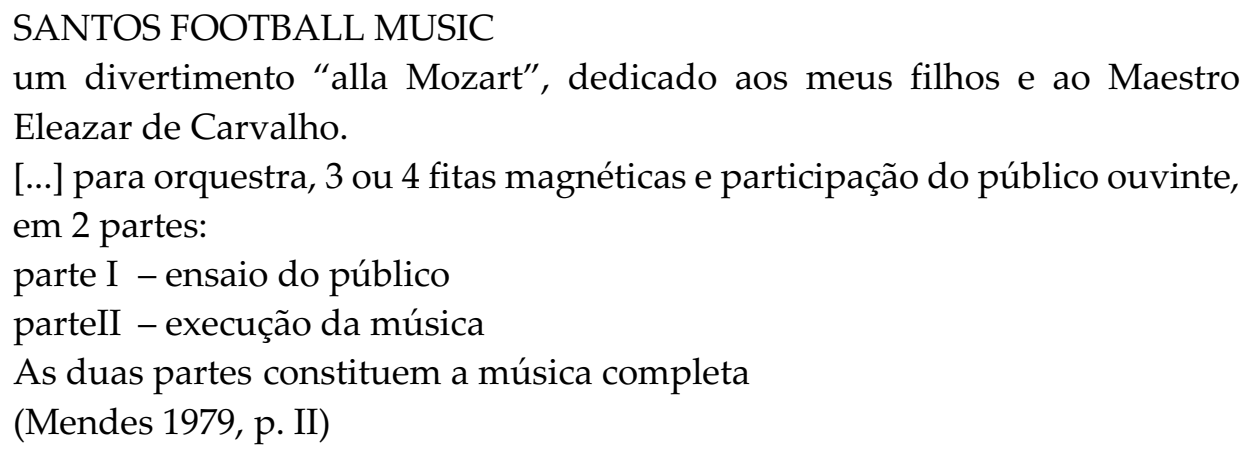

A necessidade de preparação prévia com o público é assimilada à estrutura da peça. O compositor interfere na relação a ser estabelecida com o público, subvertendo seu papel passivo na recepção de um concerto. Assim, o debate aqui proposto sobre a questão da teatralidade se relaciona a essa questão 
MUSICA THEORICA Revista da Associação Brasileira de Teoria e Análise Musical 2019, v. 4, n. 1, p. 124-159-Journal of the Brazilian Society for Music Theory and Analysis@ TeMA 2019 - ISSN 2525-5541

ainda mais ampla, de incorporação do tempo de preparação ao tempo da experiência artística completa que o compositor pretende promover. O público assume uma corresponsabilidade com a execução, tendo toda a sua experiência de recepção mediada por um conhecimento parcial do que irá transcorrer e por uma atitude de atenção distinta da mera escuta passiva. O que destaco na abordagem de Mendes é justamente a operação de trazer essas relações para o âmbito das escolhas composicionais.

\section{Seleção e organização de materiais como jogo cênico: MM51 (1976), de Mauricio Kagel}

MM51 (1976) ${ }^{11}$ é uma peça de Kagel para pianista com uso do metrônomo como objeto sônico-cênico. A presença visual e sonora do metrônomo de pêndulo remete o público ao artesanato profissional do músico e estabelece um jogo de ações e potenciais significações no âmbito da relação entre expressão sonora e passagem do tempo.

O subtítulo de MM51, "Ein Stück Filmmusik für Klavier" define a obra como uma peça de música de filme para piano. Kagel dirigiu uma realização audiovisual da peça em $1983,{ }^{12}$ que inclui a projeção de uma colagem de cenas do filme mudo Nosferatu (1922), de F.W. Murnau (1888-1931). Entretanto, o subtítulo remete ao fato ainda mais fundamental de o material musical apresentado ao ouvinte ser baseado em clichês de música descritiva: “Já com os primeiros acordes da peça, o ouvinte pode reconhecer aquele repertório de anedotas acústicas prontamente dissociáveis da ilustração de imagens em movimento"13 (Kagel 1977, "Introduction", \#1; tradução nossa). Assim, a situação musical teatral é a de um pianista tocando música relacionada a imagens em movimento, como ocorria em salas de exibição na era do cinema mudo, situação que o compositor espera que o público reconheça, com auxílio do subtítulo e devido às sonoridades, mesmo sem a projeção de imagens. Aliás, embora tenha sido

\footnotetext{
11 Partitura: Kagel (1977). Vídeo: Kagel (2017), versão em sala de concerto, $<$ https://youtu.be/usdBER8zUZU>, acesso em maio de 2019.

12 Vídeo: Kagel (1983), versão televisiva, $<$ https://youtu.be/Gu-fLh2sGT0>, acesso em maio de 2019.

13 "Already with the first chords of the piece, the listener may recognize that repertoire of acoustic anecdotes readily dissociable from the illustration of moving pictures".
} 
OLIVEIRA, H. M. Espaço, materiais e forma no teatro musical pós-1960: composição e dramaturgia em obras de Mendes, Kagel e Aperghis

utilizada para a versão audiovisual televisiva de 1983, a proposta da projeção de imagens não consta na partitura publicada em 1977.

No geral, a relação que Kagel estabelece entre música e teatro é enquadrada pela perspectiva composicional. Para ele,

torna-se normal utilizar uma maneira musical de pensar no teatro. A fala, a iluminação e o movimento se articulam como os sons, os timbres e os andamentos; o evento cênico não pode fazer sentido sem a musicalidade, porque a criação do homem de teatro inspira-se mais por verdadeiros métodos de composição musical que por todos os outros (e essa é uma das razões para eu abrir pouco a pouco meu ofício musical ao ofício teatral) (Kagel apud Bousseur 1971, p. 111-112; tradução nossa). ${ }^{14}$

Levando à frente avanços que, desde o início do século $\mathrm{XX}$, propuseram o tratamento de elementos cênicos por meio de critérios musicais, Kagel expande o alcance de seu trabalho composicional. Ao mesmo tempo, as premissas e possibilidades estéticas desse trabalho composicional são transformadas pela materialidade cênica. A situação musical teatral que está na base da criação de cada uma de suas peças coloca em movimento a formulação de critérios e ferramentas para seleção e organização de materiais sonoros e cênicos, estratégias de notação e, muitas vezes, como no caso de MM51, a coleção ou construção de objetos necessários para concretização da performance.

Pensar, de maneira musical, a ressignificação do músico como ator, o jogo a ser estabelecido no espaço cênico, incluindo materiais concretos para sua realização, e a formulação de escrituras cênicas para integrar o roteiro da performance à partitura são aspectos inferidos das abordagens de Kagel que se tornam fundamentais para compreensão da invenção de relações entre música e cena no teatro musical pós-1960.

\subsection{Colagem de fórmulas musicais e gestos estereotipados}

A situação musical/teatral que Kagel explora em MM51 remete a uma prática profissional em que pianistas executavam acompanhamento musical para projeções de filmes mudos, nos primórdios da história do cinema, nas primeiras

14 ... il devient normal d'utiliser une manière de penser musicale au théâtre. La parole, la lumière et le mouvement s'articulent comme des sons, des timbres et des tempi; l'événement scénique ne peut prendre tout son sens sans la musicalité, car la création de l'homme de théâtre s'inspire plus des véritables méthodes de composition musicale que de toutes autres (et c'est une des raisons pour moi d'ouvrir peu à peu mon métier musical au métier théâtral)." 
MUSICA THEORICA Revista da Associação Brasileira de Teoria e Análise Musical 2019, v. 4, n. 1, p. 124-159-Journal of the Brazilian Society for Music Theory

décadas do século XX. De acordo com Carrasco (2015, p. 38-44), historicamente, o acompanhamento musical de filmes, antes que surgisse a possibilidade técnica das trilhas sonoras propriamente ditas, passa por pelo menos três fases distintas. $\mathrm{Na}$ primeira fase, eram feitas seleções musicais do repertório tradicional e a execução tinha pouca ou nenhuma preocupação de sincronia com os eventos apresentados na tela. Na segunda fase, editoras passam a publicar coletâneas de peças características, música descritiva classificada em categorias abrangentes como mistério, aventura, romance, terror. Os realizadores de acompanhamentos musicais nas salas de execução tendiam cada vez mais a cortar os trechos musicais para se adequar aos eventos apresentados na tela. Por fim, na terceira fase, os filmes passam a ser distribuídos com uma planilha de seu acompanhamento musical e, em alguns casos, com as primeiras partituras originalmente compostas para filmes específicos.

Esse contexto contribui para a compreensão da intenção expressiva que motiva Kagel e que ele apresenta na introdução da partitura:

Assim como em "Acompanhamento a uma cena cinematográfica" de Schoenberg, o tema desta peça para piano é a ameaça de medos e perigos não verbalizados. Mas, em contraste com a composição orquestral de Schoenberg, que está escrita na linguagem musical autônoma do expressionismo, a presente peça usa apenas fórmulas estereotipadas, tiradas do tipo de música comercial familiar a todos os espectadores. Ao rejeitar deliberadamente um estilo "contemporâneo" atual, tentei um ponto de partida diferente para um problema que permite soluções e realizações contrastantes (Kagel 1977, “Introduction”, \#1; tradução nossa). ${ }^{15}$

Ao dialogar com a referência da peça de Schoenberg, Kagel destaca uma similaridade de ímpeto composicional e diferencia os meios de realização. Em sua abordagem, o material é constituído de fórmulas estereotipadas, dissociadas de sua função descritiva e reorganizadas em um arco formal inerente ao próprio percurso sonoro da peça. Trata-se de uma colagem de segmentos sucessivos de 4 a 16 compassos, nas quais uma determinada característica rítmica, textural e

15 "Rather as in Schoenberg's 'Accompaniment to a cinematographic scene', the theme of this piano piece is the threat of unspoken fears and dangers. But in contrast to Schoenberg's orchestral composition, which is written in the autonomous musical language of expressionism, the present piece uses only stereotyped formulae, drawn from the kind of commercial music familiar to every viewer. By deliberately rejecting a current "contemporary" style, I tried a different starting point for a problem that allows for contrasting solutions and realisations." 
OLIVEIRA, H. M. Espaço, materiais e forma no teatro musical pós-1960: composição e dramaturgia em obras de Mendes, Kagel e Aperghis

expressiva é sustentada. O segmento musical reproduzido no Exemplo 4 (a seguir), é preenchido pelo movimento rítmico em tercinas e concluído com uma pontuação no registro grave.

Em termos estruturais, a peça está organizada em três momentos distintos. No primeiro, mais longo (c. 1-91), a sucessão de segmentos musicais descortina nuances de um caráter relativamente uniforme de suspense. Num segundo momento (c. 92-136), mudanças mais pronunciadas e constantes em articulação, densidade rítmica, andamento e métrica tendem a uma maior agitação, estabelecendo caráter ameaçador. Por fim (c. 137-150), o caráter inicial é brevemente restabelecido, permanecendo, como que suspensos no ar, os medos não-verbalizados que impregnam o caráter expressivo da peça.

Na versão em sala de concerto (Kagel 2017), o jogo cênico envolvendo o pianista e o mecanismo do metrônomo (mais sobre esse aspecto abaixo, 2.2) é sobreposto à camada de sentido do percurso formal musical. A disposição do espaço sugere uma dimensão de teatralidade desde o início da performance. A ressignificação do pianista como ator se intensifica a partir da inserção de vocalizações de riso "perverso e malicioso" (Kagel 1977, p. 14-17, c. 120-136) e culmina com o gesto final da peça (p. 15, c. 149), um suspiro em que o pianista deve também levar uma das mãos ao peito. O princípio composicional de colagem, utilizado na construção da forma musical a partir de fórmulas estereotipadas de música descritiva de filmes de terror, é também aplicado à seleção e organização de ações não vinculadas à execução instrumental, procedendo a uma colagem de gestos estereotipados de vilania e medo. 

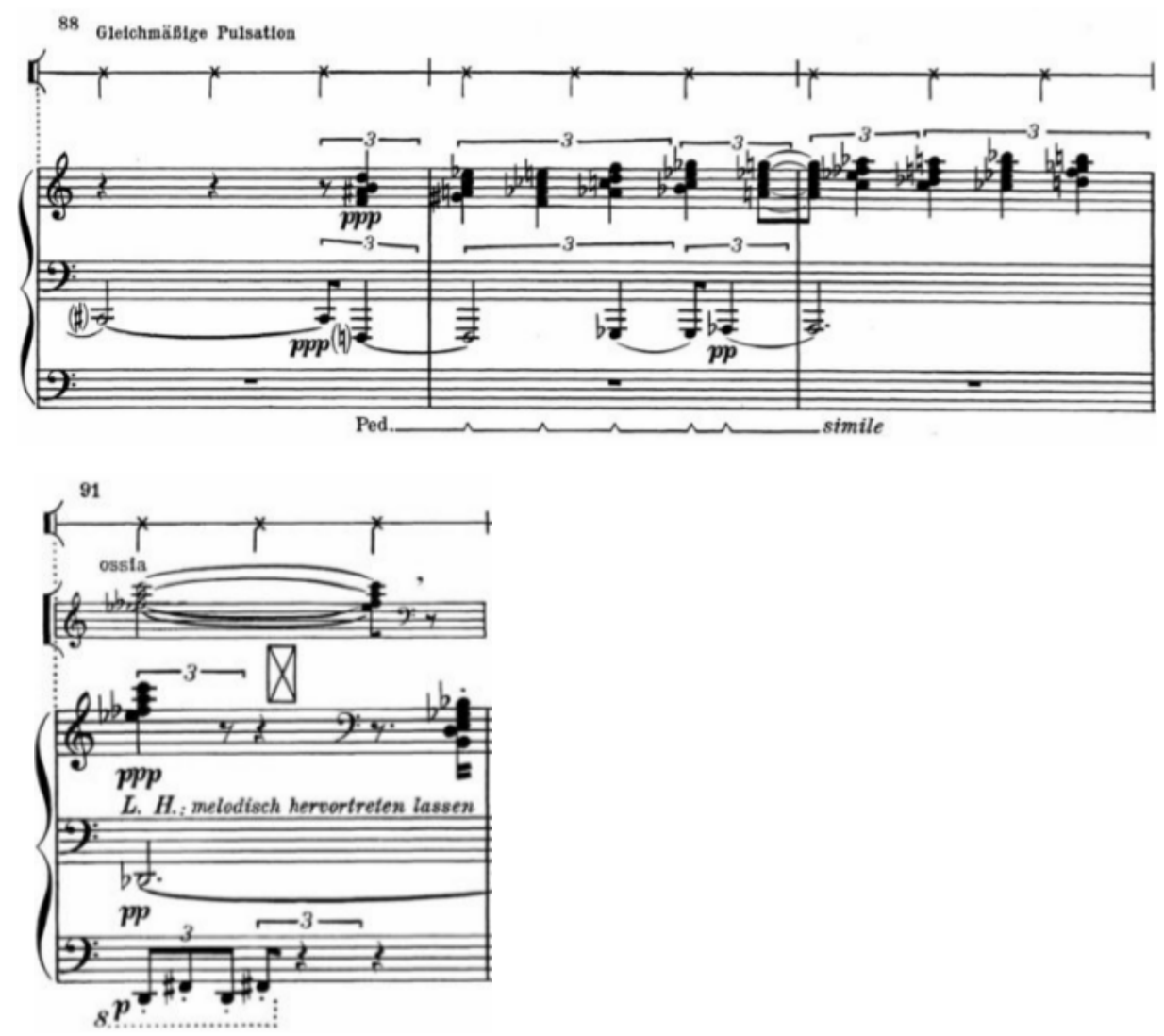

Exemplo 4: uma seção curta (c. 88-91) de MM51, de Kagel

Na versão televisiva (Kagel 1983), a sobreposição da projeção de uma colagem com cenas do filme Nosferatu não restitui as fórmulas musicais estereotipadas à sua função descritiva. A projeção adiciona uma camada de sentido à performance e possibilita que o espectador construa relações entre as camadas musical, gestual e imagética. O Exemplo 5 apresenta um trecho da partitura ao lado da imagem que, na versão televisiva é apresentada junto ao ataque do acorde do compasso 50. Nos momentos que precedem esse quadro, à medida que o material musical se direciona para o ponto de chegada da pequena seção musical, vemos uma figura aterrorizante se esgueirando pela portinhola até apoiar sua mão e voltar o olhar na direção de algo ou alguém fora do enquadramento. 
OLIVEIRA, H. M. Espaço, materiais e forma no teatro musical pós-1960: composição e dramaturgia em obras de Mendes, Kagel e Aperghis
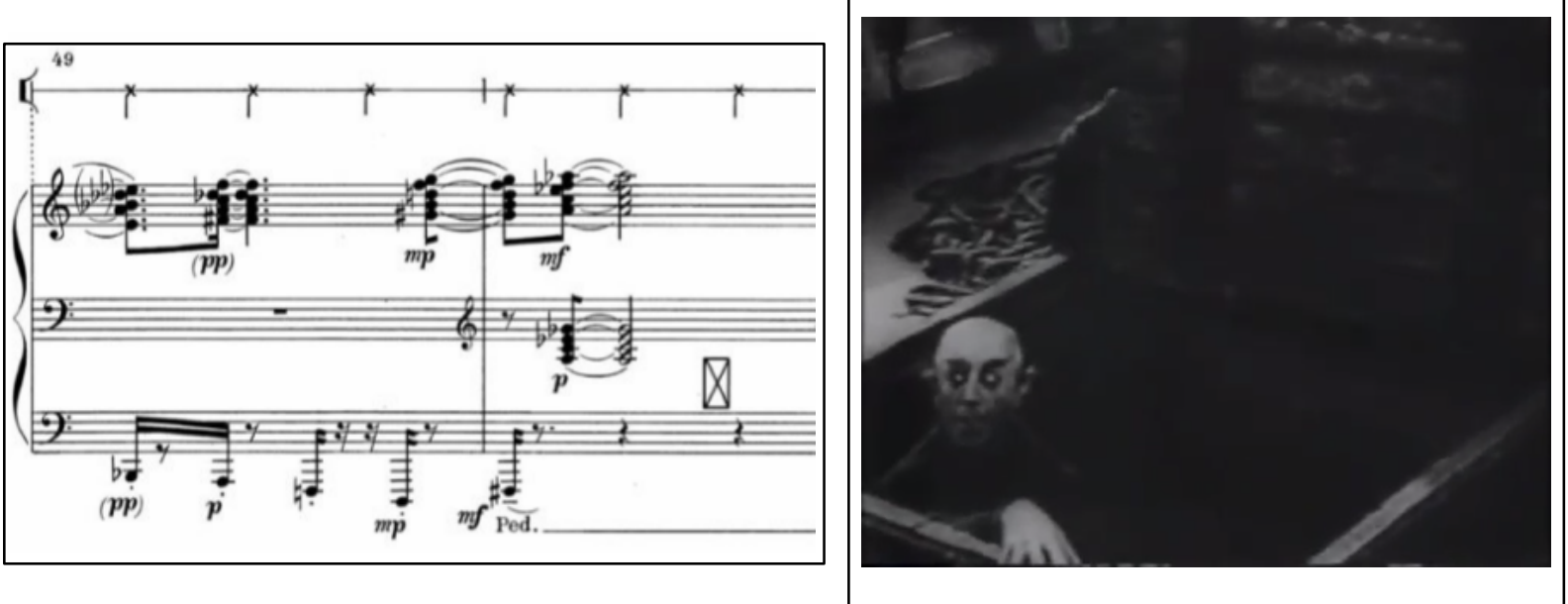

Exemplo 5: fragmento de MM51 (c. 49-50), de Kagel, à esquerda, e a imagem sincronizada com o acorde atacado com ambas as mãos (c. 50), à direita

Neste exemplo, está em jogo o que Chion (2011) designou como ilusão audiovisual. A apresentação simultânea de imagens e sons, inclusive música, tende a gerar um valor expressivo acrescentado, especialmente em situações como a descrita, em que imagem e som convergem para um ponto de sincronia, um momento inevitavelmente saliente na cadeia audiovisual (Chion 2011, p. 51). O espectador busca essas relações, independente de terem sido planejadas. Em MM51, as camadas são compostas como colagens, cada uma com sua lógica interna independente. Quando sobrepostas, ora marcham paralelamente, ora parecem convergir rítmica ou expressivamente.
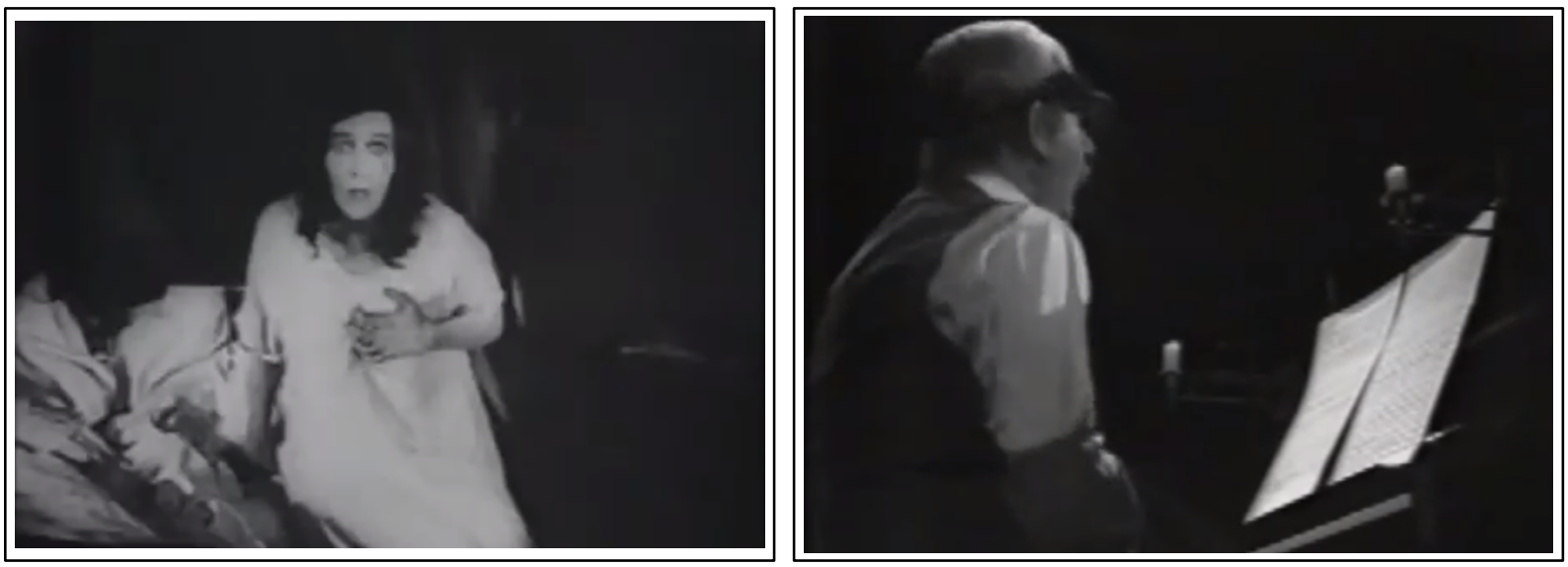

Figura 1: a figura feminina aterrorizada, da colagem de cenas de Nosferatu, e o gesto final do pianista em performance de MM51

O mesmo ocorre entre a projeção e os gestos que resignificam o músico como ator. Nessa relação, emergem paralelos, como a similaridade entre o gesto 
MUSICA THEORICA Revista da Associação Brasileira de Teoria e Análise Musical 2019, v. 4, n. 1, p. 124-159-Journal of the Brazilian Society for Music Theory and Analysis @ TeMA 2019 - ISSN 2525-5541

final do susto do pianista e a postura de uma figura feminina aterrorizada que aparece anteriormente na projeção (Fig. 1).

O material musical, os gestos e a projeção são selecionados a partir da situação musical/teatral do pianista de cinema mudo, e organizados por meio de um método composicional comum, a colagem. Paralelamente, o mecanismo do metrônomo cria mais uma camada cênica, com implicações sonoras e visuais, que alimenta a possibilidade de construção de sentidos ficcionais na recepção da performance.

\subsection{O metrônomo e o jogo sônico-cênico}

O metrônomo, regulado para o andamento de 51 batidas por minuto, e o mecanismo com o qual ele é manipulado geram um jogo sônico-cênico que não se submete de maneira óbvia à apreensão da situação musical/teatral que enquadra os sentidos de MM51: nas salas de projeção em que pianistas executavam acompanhamento musical de filmes mudos não havia metrônomos. A inserção desse elemento gera uma camada de sentido que, como as demais, segue independente, ao mesmo tempo que interage com aspectos sonoros, gestuais e visuais da performance.

Kagel dá mais de uma opção de montagem do metrônomo. A que é utilizada nas versões aqui referenciadas (Kagel 2017; Kagel 1983) preconiza que:

O metrônomo é [...]

a) montado em um hemisfério, a alguma distância do pianista (pelo menos 2 metros); um pedal operado pelo pé esquerdo leva a hemisfera a uma posição inclinada.

O metrônomo é preso à superfície plana com um imã. Esta construção é montada atrás do pianista (Kagel, 1977, “Introduction", \#3; tradução nossa). ${ }^{16}$

Assim, o mecanismo é integrado à performance do pianista que, de acordo com as instruções ao longo da partitura, deve acionar o pedal que causa a inclinação da plataforma sobre a qual o metrônomo está montado. A natureza do mecanismo é tal que a inclinação da plataforma pode levar o metrônomo a

\footnotetext{
16 "The metronome is $[\ldots]$
}

a) mounted on a hemisphere, at some distance from the pianist (at least 2 meters); a pedal operated by the left foot brings the hemi-sphere into an inclined position.

The metronome is fastened to the flat surface with a magnet. This construction is set up behind the pianist." 
OLIVEIRA, H. M. Espaço, materiais e forma no teatro musical pós-1960: composição e dramaturgia em obras de Mendes, Kagel e Aperghis

produzir pulso irregular ou interromper o pulso. Assim, no compasso 71, por exemplo, encontra-se a indicação: “O metrônomo é virado lentamente para uma posição oblíqua. (Há uma pulsação cada vez mais desigual)" (Kagel 1977, p. 8; tradução nossa). ${ }^{17} \mathrm{E}$, no compasso 84: "gradualmente restabelecer a posição normal" (Kagel 1977, p. 10; tradução nossa). ${ }^{18}$

A inserção do som do pulso gerado pelo metrônomo, que Kagel faz questão de agregar à notação da peça (ver Ex. 6, a seguir), possui uma relevante implicação para o resultado sonoro da escritura rítmica. Devido ao andamento lento, na ausência dos pulsos metronômicos, a sucessão de ataques poderia ser percebida como ritmo não métrico, uma vez que o pulso e seu agrupamento métrico não são enfatizados na escritura rítmica para o piano. Com o uso do metrônomo, nos trechos em que seu funcionamento regular é mantido, a performance e a escuta têm como um de seus focos os efeitos de deslocamento dos ataques em relação ao pulso.

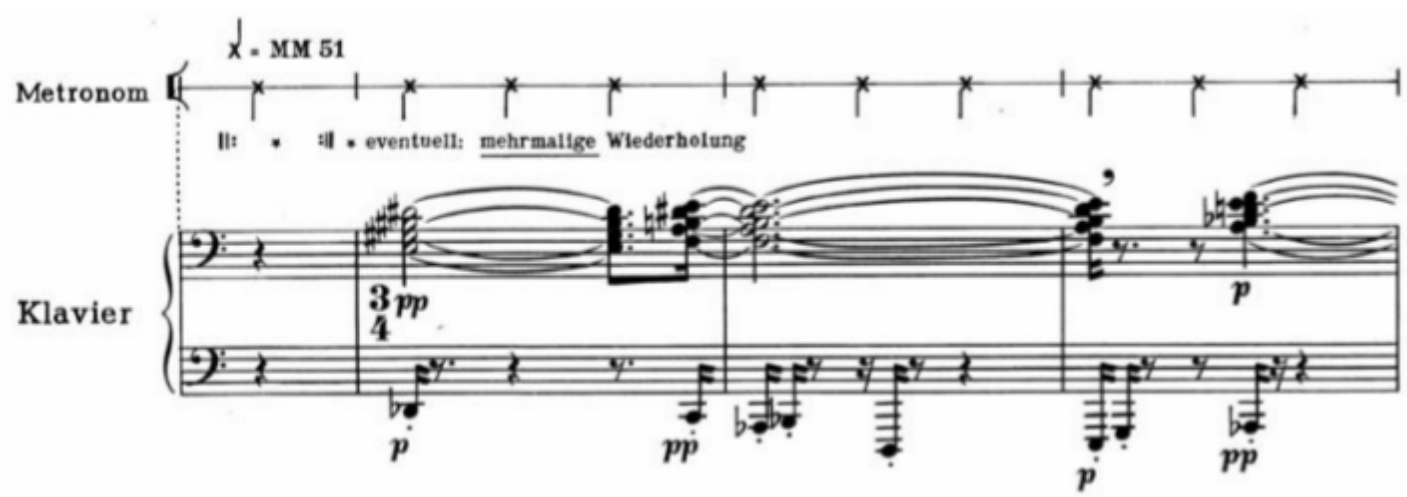

Exemplo 6: trecho inicial (c. 1-3) de MM51, de Kagel

Uma vez estabelecida essa relação fundamental de referência métrica, e valendo-se do mecanismo criado para montagem do metrônomo em cena, Kagel explora uma série de interações. O Quadro 1 apresenta a sequência de indicações do pulso metronômico e a sua relação com a execução ao piano.

\begin{tabular}{|l|l|l|l|}
\hline Localização na partitura & $\begin{array}{l}\text { Piano (fórmula de } \\
\text { compasso e andamento) }\end{array}$ & Metrônomo (pulso) & Relação \\
\hline c. $1-71$ & $3 / 4 \cdot=51$ & Regular (51 b.p.m.) & sincronia \\
\hline
\end{tabular}

17 "Metronom äußesrt langsam in schräge Lage bringen. (Es enisteht eine zunehmend ungleichmäßige Pulsation)"

18 "Allmählich in normal Lage bringen" 
MUSICA THEORICA Revista da Associação Brasileira de Teoria e Análise Musical 2019, v. 4, n. 1, p. 124-159-Journal of the Brazilian Society for Music Theory and Analysis@ TeMA 2019 - ISSN 2525-5541

\begin{tabular}{|l|l|l|l|}
\hline c. $72-87$ & $3 / 4 \cdot=51$ & Irregular & aleatória \\
\hline c. $88-96$ & $3 / 4 \cdot=51$ & Regular $(51$ b.p.m.) & sincronia \\
\hline c. $97-103$ & $3 / 4 \cdot=51$ & Irregular & aleatória \\
\hline c. $104-119$ & $9 / 8 \cdot=102$ & Tacet & - \\
\hline c. $120-124$ & $3 / 4 \cdot=51$ & Regular $(51$ b.p.m.) & sincronia \\
\hline c. $125-139$ & $9 / 8 \cdot=68$ & Regular $(51$ b.p.m.) & $\begin{array}{l}\text { Assincronia ou } \\
\text { polirritmia }\end{array}$ \\
\hline c. $140-150$ & $9 / 8 \cdot:=102$ & Tacet & - \\
\hline
\end{tabular}

Quadro 1: o pulso metronômico e sua relação com o material musical do piano em MM51, de Kagel

O pulso regular soando em sincronia com a execução do piano está presente em três trechos (c. 1-71, 88-96 e 120-124). Em outro trecho (compassos 125-139), o "metrônomo continua a correr independente do andamento da execução" (Kagel 1977, p. 15; tradução nossa). ${ }^{19}$ Aqui, o efeito pode ser de assincronia, com a simultaneidade de dois pulsos, ou de polirritmia, se a precisão de início da execução do trecho e dos andamentos indicados na partitura for mantida. Nesse caso, o pulso metronômico soaria a cada quatro colcheias em uma periodicidade distinta daquela que rege os agrupamentos rítmicos na fórmula de compasso 9/8. O pulso irregular, resultando em uma relação ritmicamente aleatória entre os pulsos gerados pelo metrônomo e a rítmica gerada pelo piano, está presente em dois trechos distintos (c. 72-87 e 97-103). Por fim, há dois trechos (c. 104-119 e 140-150) em que o metrônomo é colocado em pausa.

A interação entre o metrônomo e o piano desencadeia um processo formal independente, em contraponto com a estrutura em três partes descrita na seção anterior. Por meio do mecanismo de manipulação do metrônomo, Kagel compõe variantes de um parâmetro sonoro e suas relações com os demais materiais sonoros da peça. Organiza essas variantes e relações de maneira a gerar um senso de coerência e direção.

A presença visual e sonora do metrônomo e do mecanismo construído para sua manipulação também cria uma camada adicional de sentido para o jogo cênico. Deve ser montado atrás do pianista, de tal forma que seu olhar nunca está

19 “Metronom läuft weiter unabhängig vom Spieltempo" 
OLIVEIRA, H. M. Espaço, materiais e forma no teatro musical pós-1960: composição e dramaturgia em obras de Mendes, Kagel e Aperghis

direcionado ao mecanismo. Na versão televisiva (Kagel 1983), esse aspecto é ainda mais proeminente: o pianista tem seu olhar voltado para a tela de projeção, permitindo ao ouvinte/espectador atribuir o sentido de uma relação consciente, profissional e intencional entre suas ações e as imagens em movimento, relação claramente similar àquela que haveria na situação real do pianista de cinema mudo. As flutuações do mecanismo do metrônomo, entretanto, não são pertinentes à situação real e estão como que ocultas da figura cênica do instrumentista.

Assim, para além das funções sonoras e formais descritas nos parágrafos anteriores, o mecanismo do metrônomo passa a interferir na representação, nos sentidos construídos na performance. Representa aspectos que tendem a permanecer inconscientes nas atitudes e ofícios cotidianos do músico. No suspiro final (c. 149), a apresentação deliberada de figuras e cenas estereotipadas de terror dá lugar ao sobressalto que acomete o pianista quando aparentemente toma consciência da previsibilidade e rigidez de seu artesanato profissional.

\section{Estrutura e forma como encenação: Graffitis (1980), de Georges Aperghis}

Para Georges Aperghis (n. 1945) (apud Trubert 2015, p. 1281), o trabalho a que se propõe é de inventar maneiras de relacionar música e teatro distintas daquelas herdadas da ópera ou do concerto. Em obras como 7 crimes de l'Amour $(1979)^{20}$ e Retrouvailles (2013), ${ }^{21}$ ele parte de situações que emulam o realtriângulo amoroso e dois conhecidos numa mesa de bar, respectivamente -, mas que perdem sua factibilidade devido às manipulações composicionais da voz e dos gestos.

Já em Graffitis, Aperghis elabora o material cênico a partir da própria execução instrumental, explorando a irrupção do gesto e a teatralidade latente da percussão múltipla e das vocalizações. Em outra obra percussiva, Les guetteurs de sons (1981), ${ }^{22}$ fica evidenciada uma abordagem composicional semelhante. Aqui,

\footnotetext{
${ }^{20}$ Partitura: Aperghis (2006a). Vídeo: Aperghis (2013a), $<$ https://youtu.be/aZ48kO LiRs $>$, acesso em maio de 2019.

${ }^{21}$ Partitura: Aperghis (2013c). Vídeo: Aperghis (2013d), <https://youtu.be/0-3LFmAf DM>, acesso em maio de 2019.

${ }^{22}$ Partitura: Aperghis (2006c). Vídeo: Aperghis (2011a), <https://youtu.be/7ly1VuBMQuk>, acesso em maio de 2019.
} 
MUSICA THEORICA Revista da Associação Brasileira de Teoria e Análise Musical 2019, v. 4, n. 1, p. 124-159-Journal of the Brazilian Society for Music Theory and Analysis@ TeMA 2019 - ISSN 2525-5541

o gesto de execução musical, dissociado de sua implicação sonora, assume o primeiro plano em diversos momentos da performance: decomposição do gesto percussivo, sua realização com ou sem implicação sonora e sustentação de posturas corporais em longas pausas. Em prefácio disponibilizado junto à partitura, Gaston Sylvestre (apud Aperghis 2006c), um dos três artistas a quem essa peça foi dedicada, complementa a leitura cênica da peça. Para ele, é possível atribuir uma persona a cada percussionista, sugerindo que sua gestualidade deva refletir tanto essa caracterização, quanto o desenvolvimento da narrativa da peça, do nascimento à morte.

No contexto geral do teatro musical de Aperghis, tanto a situação teatral é apresentada e desenvolvida como performance musical, quanto gestualidade e visualidade da performance musical são desenvolvidas a ponto de adquirir sentido teatral. Lidar com o deslizamento entre performance (apresentação de ações inerentes ou não à execução vocal e instrumental) e representação (construção ou sugestão de uma narrativa ficcional no espaço cênico) é uma questão relevante para compreensão do trabalho do compositor grego radicado na França, como verificamos também em Mendes e Kagel.

\subsection{Da vocalização à linguagem, da linguagem ao teatro musical}

Em entrevista de 2010, Aperghis discorria sobre duas maneiras de ir da linguagem ao teatro musical:

A primeira é remover o significado, removendo pedaços de palavras, ou não colocando as palavras onde elas deveriam estar para dar significado, mas, ao contrário, colocá-las para fazer música. A partir daí, a partir do momento em que não entendemos, ouvimos, porque tentamos entender, e é isso que torna esse fenômeno muito musical. O público se pergunta: o que é isso? É uma linguagem? É outra coisa? E, a propósito, é o mesmo para o teatro musical (Aperghis apud Donin; Trubert 2010; tradução nossa). ${ }^{23}$

A primeira maneira consiste, portanto, em um trabalho de fragmentação do texto ao nível sintático (reordenação de palavras) e fonético (reordenação de fonemas), reorganizando as sonoridades vocais por meio de procedimentos

23 “La première c'est d'enlever du sens, en enlevant des bouts de mots, ou en ne mettant pas les mots où ils doivent être pour donner sens mais au contraire, de les placer pour faire de la musique. À partir de là, à partir du moment où on ne comprend pas, on écoute, parce qu'on essaye de comprendre, et c'est ça qui rend ce phénomène très musical. Le public s'interroge : $c^{\prime}$ est quoi ? C'est une langue ? C'est autre chose ? Et d'ailleurs c'est pareil pour le théâtre musical." 
OLIVEIRA, H. M. Espaço, materiais e forma no teatro musical pós-1960: composição e dramaturgia em obras de Mendes, Kagel e Aperghis

composicionais. A intenção expressiva é provocar a escuta atenta a partir de uma experiência de estranhamento com o deslocamento do propósito de gestos vocais originados da linguagem. As ações são reconhecidas como quase palavras, embora não resultem em mensagens reconhecíveis.

Alternativamente, ao invés de remover o significado, o compositor se propõe a acrescentá-lo, até o limite. “A outra maneira é acrescentar muito, como uma linguagem sobredeterminada, mas com tantos meandros e contradições que finalmente não sabemos em absoluto sobre o que falamos, como uma espécie de redemoinho" (Aperghis apud Donin; Trubert 2010; tradução nossa). ${ }^{24}$ Nesse caso, a intervenção é diretamente ao nível semântico. Enquanto as unidades sintáticas são mantidas intactas, sua proliferação macarrônica dissolve o sentido geral da ação vocal rumo a uma musicalidade/teatralidade peculiar. Essa abordagem é uma das possibilidades exploradas em Luna Park (2011). ${ }^{25}$

Aperghis também constrói vocalizações com uso de sílabas onomatopaicas. Esse tipo de escrita integra as vocalizações à textura percussiva. Ora a voz alterna com o instrumento de percussão, ora são combinados verticalmente, como na primeira seção de Le corps à corps (Aperghis 2006b, p. 19) (ver Ex. 7).

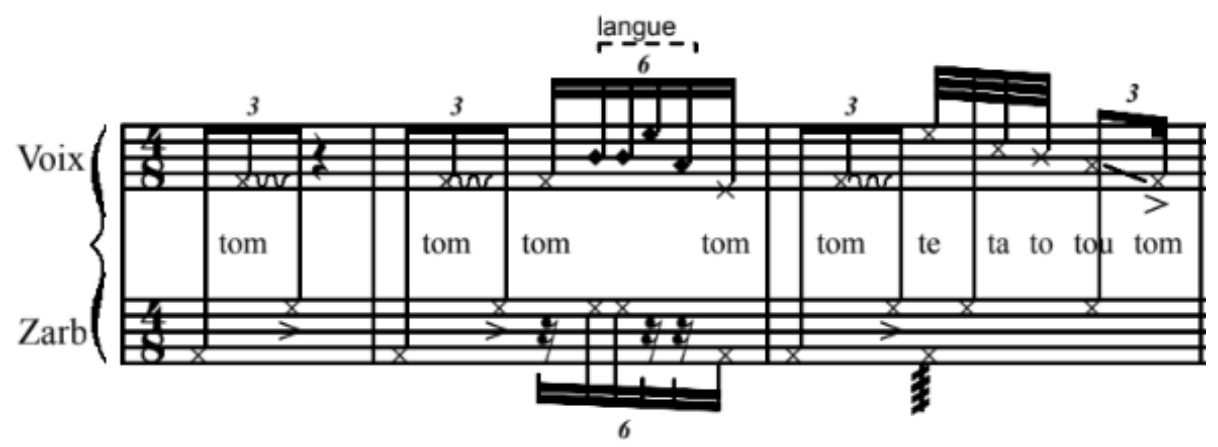

Exemplo 7: a escrita para percussão e voz com sílabas onomatopaicas nos três primeiros compassos da página 4 da partitura de Le corps à corps, de Aperghis

24 “L'autre façon, c'est d'en ajouter énormément, comme un langage surdéterminé, mais avec tellement de méandres et de contradictions que finalement on ne sait plus du tout de quoi on parle, comme une espèce de tourbillon."

25 Vídeo: Aperghis (2011b), <https://youtu.be/biTGIRROgZA>, acesso em maio de 2019. 
MUSICA THEORICA Revista da Associação Brasileira de Teoria e Análise Musical 2019, v. 4, n. 1, p. 124-159-Journal of the Brazilian Society for Music Theory and Analysis@ TeMA 2019 - ISSN 2525-5541

Em Graffitis, o material vocal é construído, inicialmente com sílabas onomatopaicas e, depois, com a primeira maneira de ir da linguagem ao teatro musical descrita acima. Um pequeno trecho do Fausto (1832), de Johann Wolfgang von Goethe (1749-1832), é fragmentado e apresentado gradativamente, de tal maneira que, a partir de um certo ponto na performance, seu sentido semântico emerge (para os ouvintes familiares com o idioma alemão).

Procedimentos de apresentação progressiva dos materiais são característicos em Aperghis. Frequentemente, na sua escrita, uma unidade lógico-temporal é recortada e redistribuída pela partitura em sequências mais ou menos aleatórias de interjeições sonoras. "Acontece assim que uma seção pode ser ao mesmo tempo totalmente emancipada de qualquer continuidade lógica e, ao mesmo tempo, completamente integrada a um vasto processo de elaboração que mantém a coerência do trabalho" (Donin; Trubert 2010; tradução nossa). ${ }^{26} \mathrm{~A}$ impressão de materiais sonoros entrecortados e fragmentados é sustentada, ao mesmo tempo que gradativamente emerge um senso de direção formal, decorrente da coerência de procedimentos e da gradativa completude dos materiais.

Em Graffitis, especificamente, não há um procedimento único que seja concretizado de maneira ininterrupta e corresponda à própria forma da peça. Uma série deles são aplicados e interpolados com outros materiais que podem resultar de procedimento similar ou de escolhas mais pontuais para gerar as sucessivas seções da peça. Entre as páginas 1 e 2, a construção progressiva de uma série fixa de sílabas onomatopaicas ("do i vo do va man..." etc.) é interpolada com materiais percussivos (Ex. 8).

\footnotetext{
26 "Il advient ainsi qu'une section puisse être à la fois totalement émancipée de toute continuité logique, et en même temps complètement intégrée à un vaste processus d'élaboration qui maintient la cohérence de l'œuvre."
} 
OLIVEIRA, H. M. Espaço, materiais e forma no teatro musical pós-1960: composição e dramaturgia em obras de Mendes, Kagel e Aperghis
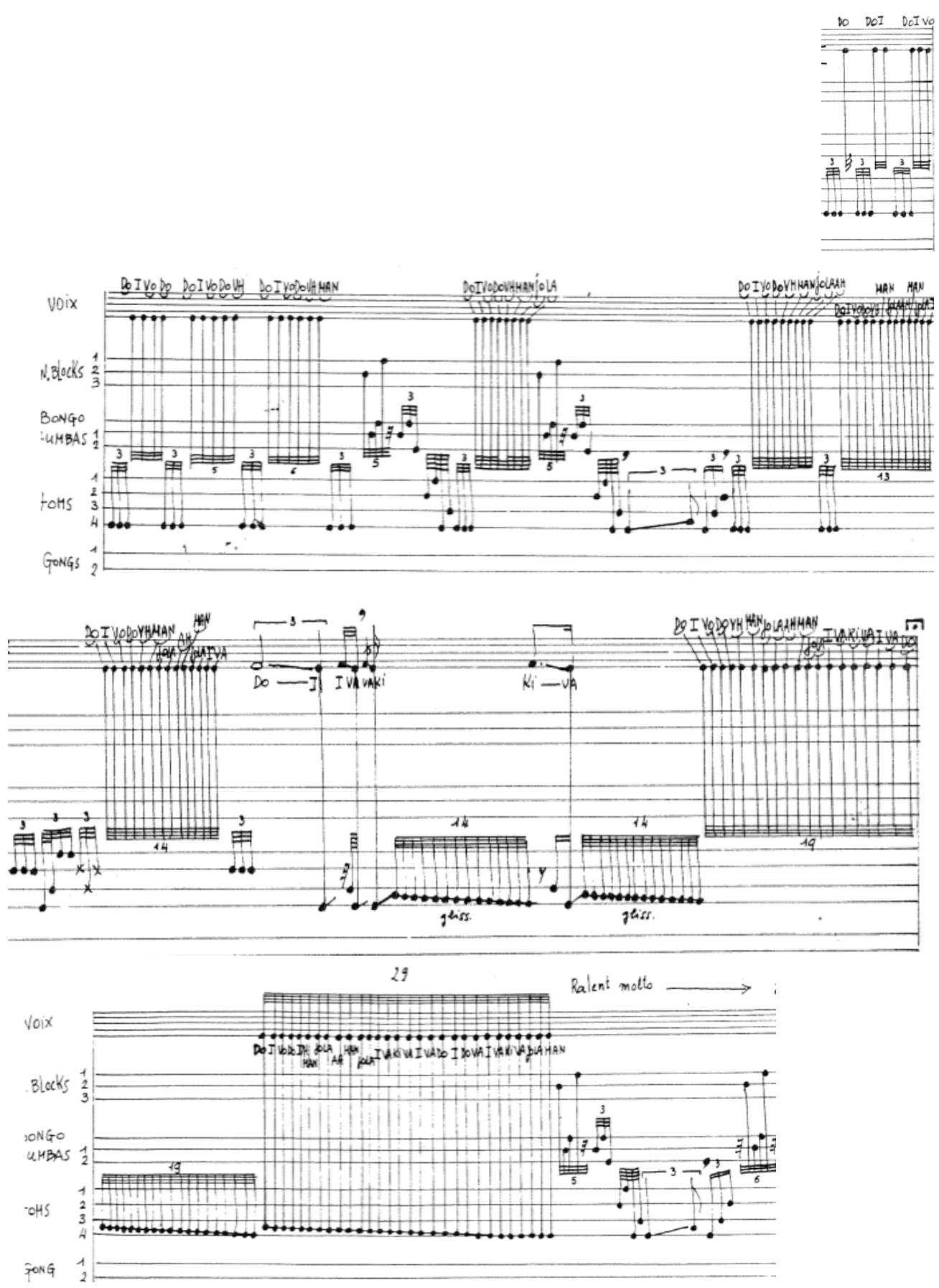

Exemplo 8: procedimento composicional de construção progressiva de uma sequência de vocalização de sílabas onomatopaicas em trecho das páginas 1 e 2 da partitura de Graffitis, de Aperghis

A forma da peça emerge de uma série de processos interligados. Quanto às vocalizações, em um primeiro momento são apresentadas sílabas onomatopaicas. Depois, sílabas e palavras em alemão são inseridas na textura. Por fim, a declamação rítmica do texto em alemão passa ao primeiro plano da 
MUSICA THEORICA Revista da Associação Brasileira de Teoria e Análise Musical 2019, v. 4, n. 1, p. 124-159-Journal of the Brazilian Society for Music Theory and Analysis @ TeMA 2019 - ISSN 2525-5541

performance vocal. Paralelamente, a relação entre vocalização e percussão também é transformada no decorrer do tempo da peça. Inicialmente, as vocalizações aparecem como fonte sonora em uma textura percussiva. Gradativamente, a declamação textual ganha proeminência até o ponto em que passa a ser acompanhada apenas por gestos de execução instrumental, realizados, entretanto, sem implicação sonora (Ex. 9). O Exemplo 9 mostra as transformações das vocalizações e sua relação com a parte percussiva ao longo da partitura: a) declamação do texto alternada com sílabas onomatopaicas e acompanhamento percussivo (p. 6, $3^{\circ}$ sistema); b) palavras do texto alternadas com células percussivas (p. 7, $3^{0}$ sistema); c) declamação do texto com acompanhamento de gestos de execução percussiva (p. 9, 1ํㅗㄴ sistema).
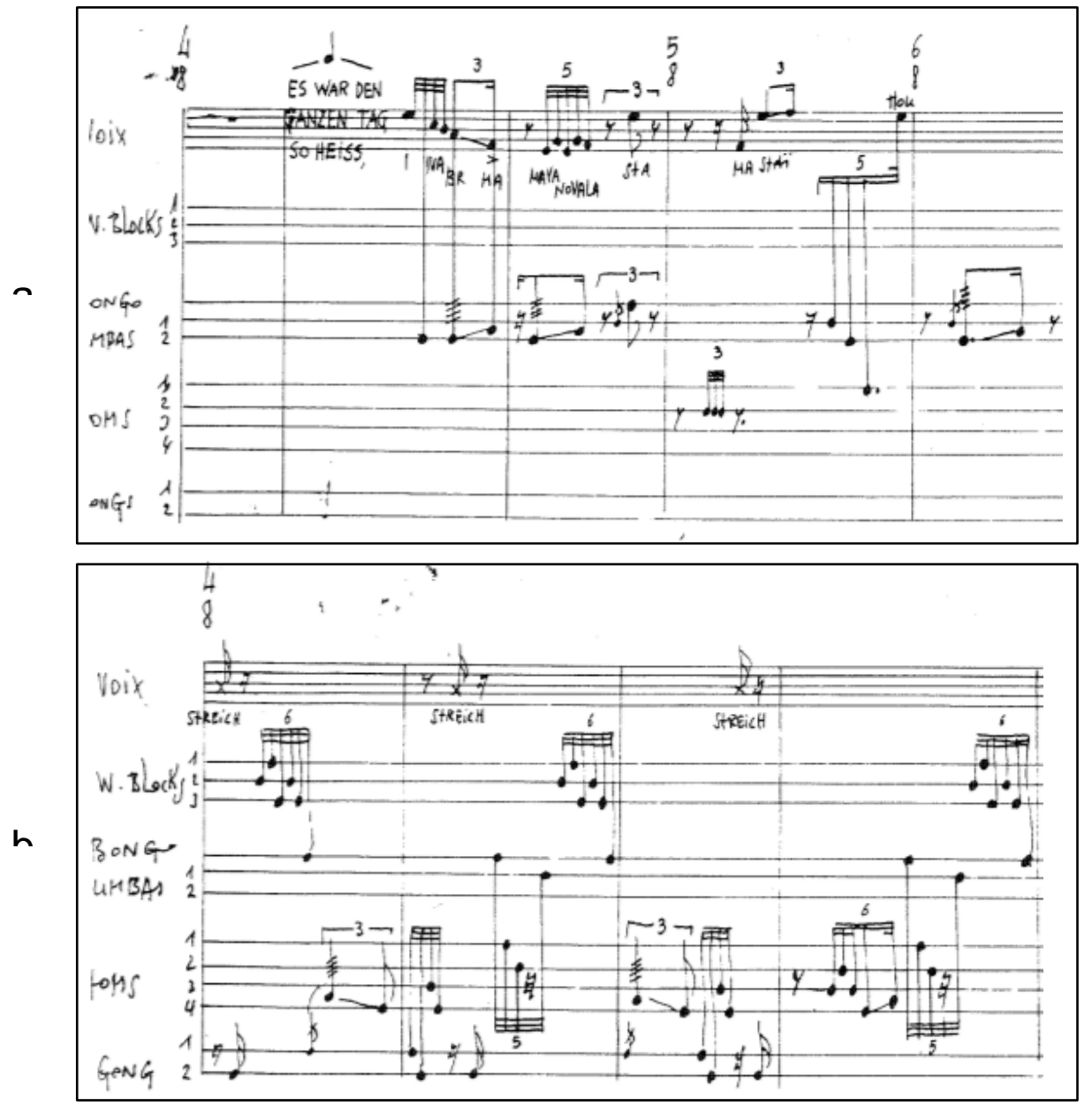
OLIVEIRA, H. M. Espaço, materiais e forma no teatro musical pós-1960: composição e dramaturgia em obras de Mendes, Kagel e Aperghis

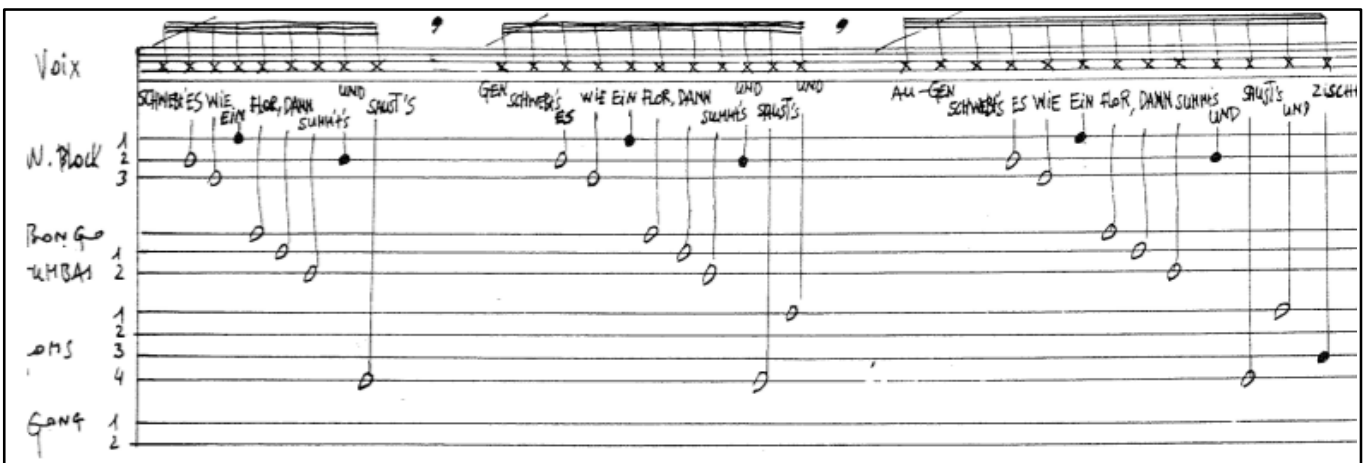

Exemplo 9: fragmentos de diferentes partes de Graffitis, de Aperghis

Essa sequência na organização dos materiais delineia um percurso da vocalização à linguagem e da linguagem ao teatro musical. Especificamente, a cena construída funciona como uma espécie de melodrama em que o percussionista exerce, simultaneamente, as funções de narrador e acompanhamento instrumental.

\subsection{Da abertura à narrativa}

A partir da página 6 da partitura de Graffitis, Aperghis inicia a roteirização de uma sequência de ações não vinculadas à execução instrumental que enfatiza a ressignificação do músico como ator e que se revela como solução formal para o desdobramento e, eventualmente, desfecho da peça. A primeira dessas ações é olhar para um par de baquetas. ${ }^{27}$ Em uma série de interrupções à execução vocal/instrumental, indicadas nas páginas seguintes, a sequência de ações é gradativamente complementada, em mais uma instância do procedimento composicional de construção progressiva.

Os processos formais de toda a peça são construídos por interpolações diversas em que sonoridades e ações são reveladas gradativamente e em alternância com os demais materiais. Estes, por sua vez, submetidos também a procedimentos similares de fragmentação e construção gradativa. O performer vai da vocalização onomatopaica à linguagem e, nos termos do compositor, da linguagem ao teatro musical, ao mesmo tempo em que a relação entre voz e percussão vai da textura rítmica à declamação acompanhada de gestos. $\mathrm{O}$

\footnotetext{
${ }^{27} \mathrm{Na}$ página de rosto, Aperghis faculta ao performer escolher instrumentos e objetos distintos daqueles indicados na partitura. No texto, faço referência predominantemente ao roteiro conforme consta na partitura.
} 
MUSICA THEORICA Revista da Associação Brasileira de Teoria e Análise Musical 2019, v. 4, n. 1, p. 124-159-Journal of the Brazilian Society for Music Theory and Analysis@ TeMA 2019 - ISSN 2525-5541

resultado estético é de uma performance que vai da execução musical à atuação cênica.

Na seção anterior, chamava atenção para paralelos entre Graffitis e Le corps à corps, quanto à escrita vocal e quanto à relação entre vocalização e percussão. Entretanto, os paralelos entre as peças não estão restritos àqueles aspectos e são particularmente profícuos para a compreensão do aspecto estrutural. Em Le corps à corps, Aperghis explicitava a segmentação da partitura em dois movimentos: "I. Ouverture" e "II. Le recit" (Aperghis 2006b, p. 1, p. 9). O início do segundo movimento, o conto, é precedido pela pronúncia das primeiras palavras inteligíveis do texto (ali, em francês) e por uma breve interrupção da execução vocal-instrumental pela ação: "vire a cabeça para a direita, como se estivesse surpreso com algo" (Aperghis 2006b, p. 9; tradução nossa). ${ }^{28}$

Em Graffitis, embora a segmentação não venha indicada com subtítulos, a estrutura utilizada por Aperghis é exatamente a mesma. Após a abertura, a execução vocal-instrumental é interrompida por uma ação de olhar, seguindo-se a apresentação gradativa da narrativa. Há, entretanto, uma diferença relevante. Em Le corps à corps, a ação de olhar é repetida para marcar as sucessivas retomadas da narrativa, apresentada em construção progressiva. Em Graffitis, a ação de olhar, ao ser repetida, não apenas marca a retomada da narrativa (e sua apresentação gradativa que mescla, nesse caso, procedimentos de construção progressiva, bidirecional e retrógrada). ${ }^{29}$ Mas, é também acrescida de outras ações (em seu próprio processo de construção progressiva), culminando no momento final em que o performer pega as baquetas e as luzes se apagam.

O exame do texto declamado, retirado de um episódio do Fausto de Goethe em que um soldado descreve a selvageria e absurdidade da experiência do campo de batalha, revela uma nova camada de sentido. Ainda que as qualidades fragmentadas e repentinas da execução vocal e instrumental possam ser relacionadas a posteriori com a violência e a desorientação referenciadas pelo conteúdo semântico do texto, a relação entre os materiais musicais, cênicos e textuais não é de modo algum ilustrativa. A passagem literária, embora seja fragmento de texto do gênero dramático, não é o ponto de partida para a

\footnotetext{
28 "tournez la tête à droite, comme si vous étiez surpris par quelque chose"

${ }^{29}$ Para uma discussão de procedimentos composicionais em Le corps à corps, ver Dos Santos et al (2015).
} 
OLIVEIRA, H. M. Espaço, materiais e forma no teatro musical pós-1960: composição e dramaturgia em obras de Mendes, Kagel e Aperghis

concepção teatral. É agregada à peça como mais um de seus materiais sonoros e dispositivos de construção de sentido.

Cada camada da composição prossegue com suas próprias lógicas internas e potenciais de sentido, de tal maneira que se desenham distintos arcos narrativos e representacionais. Em uma camada, a própria performance encena um percurso da execução musical à atuação cênica. Em outra camada, a sequência de ações introduzidas a partir da página 6 da partitura precipita a eventual dissolução da performance ao sugerir, na figura do performer, a representação de alguém dividido entre a responsabilidade de executar um roteiro de ações e o desejo de apanhar algo que lhe falta, mas se encontra fora de seu alcance. Note-se que a execução percussiva é toda realizada com as mãos e o objeto sugerido pelo compositor é justamente um par de baquetas. ${ }^{30}$ Em outra camada, o percussionista é ressignificado como narrador melodramático relatando a história do texto, ainda que essa representação seja distorcida pelas manipulações composicionais da vocalização e da corporalidade do músico/ator.

As soluções composicionais para organização dos materiais correspondem simultaneamente, por um lado à coerência e senso de direção musical e, por outro lado, à proposta de concretização cênica da peça, ou seja, sua encenação. A teatralidade decorre das próprias condições criadas para a performance, passando ao largo da questão da verossimilhança. Há aqui, novamente, um importante ponto de contato com as discussões teóricas em artes cênicas. No que se refere às experimentações cênicas pós-1960, campo no qual se enquadra por analogia o teatro musical de Aperghis e demais obras discutidas neste trabalho, a noção de teatralidade é menos um dado assumido a priori que um resultado da própria proposta criativa.

Ao abordar a teatralidade como dimensão estética da música de concerto, o processo de representação é indissociável do transcorrer da execução musical no tempo real de performance. E é nesse sentido que, em uma peça como Graffitis, as escolhas composicionais relacionadas à estrutura (divisibilidade em partes) e à forma (disposição dos conteúdos e suas continuidades) musicais implicam na criação de condições para a concretização cênica da performance.

\footnotetext{
${ }^{30} \mathrm{O}$ compositor, entretanto, faculta a substituição dos objetos. Em uma alternativa teatralmente interessante, o percussionista Alexander Wnuk (Aperghis 2014) utiliza uma taça de vinho. Nesse caso, o desejo adquire um sentido narrativo externo à execução musical e, talvez até, de fuga à responsabilidade da performance.
} 


\section{Considerações finais: composição e dramaturgia}

A dramaturgia, entendida como função de organização de eventos cênicos, ou seja, como composição, coloca-se como noção privilegiada para explicitar as investigações criativas de compositores interessados na teatralidade da performance musical.

Para Danan (2010), “a dramaturgia não é talvez nada além do pensamento do teatro em marcha, pensamento sempre em vias de se constituir [...]" (p. 119120). E esse pensamento "constitui por sua vez um motor, o que põe em movimento e ordena a ação, as ações - as organiza, as dispõe - segundo uma certa ordem, que se pode denominar composição" (p. 120). Ao se desvencilhar de convenções da fábula, a dramaturgia passa a ter um sentido mais geral de organização do evento cênico e articulação de seus elementos, de composição.

Não se limita, portanto, à autoria de textos do gênero dramático e à figura do autor, concepção predominante na produção teatral do século XIX. Ela abarca as transformações e experimentações teatrais no século $X X$, bem como a incorporação de métodos de geração e organização de material para a cena oriundos de outras linguagens artísticas e a descentralização dos processos criativos para a cena (Mota 2017, p. 35). Ao invés de se constituir como técnica inequívoca para construção de uma peça, a dramaturgia "passa a ser compreendida [...] como um campo semântico de tensões criativas" (Torres Neto 2016, p. 162), decorrentes das propriedades, dinâmicas e possibilidades de sentido das distintas materialidades apresentadas no espaço cênico.

O trabalho de ordenamento das sonoridades e ações composição/dramaturgia - realizado pelos compositores ligados ao teatro musical pós-1960 decorre de um pensamento da situação musical/teatral em marcha e em constituição. As escolhas composicionais são suscetíveis às tensões ocasionadas pelas distintas demandas, propriedades e dinâmicas das materialidades visuais, gestuais e sonoras.

Ao discutir obras específicas de Mendes, Kagel e Aperghis, abordei três categorias dessas escolhas composicionais. Na primeira categoria, a situação de performance musical é abordada como espaço cênico, considerando escolhas composicionais referentes ao lugar, à disposição e tipo de relação entre músicos e público e ao emprego de outros elementos visuais - objetos, figurinos, iluminação. Na segunda categoria, a seleção, invenção e organização de materiais é abordada como estabelecimento de um jogo cênico, no qual a gestualidade da 
OLIVEIRA, H. M. Espaço, materiais e forma no teatro musical pós-1960: composição e dramaturgia em obras de Mendes, Kagel e Aperghis

execução instrumental é teatralizada pela manipulação de múltiplas fontes sonoras e outros objetos, pela organização rítmica das ações e interações e, eventualmente, por vocalizações e por ações não vinculadas à execução musical. $\mathrm{Na}$ terceira categoria, estrutura (divisibilidade em partes) e forma (conteúdos e suas continuidades) são abordadas como encenação, na qual as ações são concatenadas em episódios sonoro-gestuais e em percursos narrativos. $\mathrm{O}$ pensamento sobre a organização da peça como um todo coordena as considerações estruturais/formais musicais e a colocação em cena do mesmo material, levando em conta aspectos técnicos e artísticos para concretização da performance.

A concepção atual de dramaturgia considera a presença do ator, seus gestos e sua voz, bem como os demais elementos da encenação, de maneira autônoma, com potencial de construir seus próprios discursos cênicos (Torres Neto 2016, p. 162). No teatro musical pós-1960, as relações entre o músico/ator, a ficção da situação musical/teatral e o jogo das ações, interações e materialidades apresentadas no espaço cênico da performance musical são múltiplas. A abrangência das escolhas composicionais é estendida para o âmbito dessas relações, compondo, de fato, distintas possibilidades de constituição e desenvolvimento do processo de teatralidade.

Nas propostas mais radicais desse teatro musical pós-1960, o nexo narrativo é quase totalmente abolido. O texto dramático, como dado a priori para o trabalho composicional em teatro musical, perde seu caráter unificante (Trubert 2015 , p. 1279), dando origem a um processo de teatralidade que pode ser compreendido à luz de sua tensão com a performatividade. Tanto o ator - por sua concretude corporal no interior do espaço cênico - quanto o jogo - pela maior ou menor arbitrariedade de suas convenções - mediam o aspecto de performance, como apresentação de ações, com o aspecto de representação, como significação ficcional dessas mesmas ações. Há uma dinâmica de permanente disjunção-unificação entre as estruturas simbólicas do teatro e os fluxos energéticos que se atualizam na performance (Féral 2015, p. 112).

Nas transformações da criação cênica no século $X X$, a performatividade ganha um maior peso: "diversos autores e encenadores buscaram criar essa dissociação unívoca entre um discurso (verbal ou visual) e um sentido dado" (Féral 2015, p. 118-119). O teatro assume, em diversos graus e variações, o caráter de descrição dos acontecimentos em detrimento da narrativa ficcional e de 
MUSICA THEORICA Revista da Associação Brasileira de Teoria e Análise Musical 2019, v. 4, n. 1, p. 124-159-Journal of the Brazilian Society for Music Theory and Analysis@ TeMA 2019 - ISSN 2525-5541

criação de espetáculos centrados na imagem e na ação em detrimento do texto. A noção de teatralidade, à luz desses desdobramentos na história da criação teatral, remete a um teatro em que "o sentido deixa completamente de ser global; é sempre local e fragmentário" (Sarrazac 2009, p. 28).

A partir dessa ruptura fundamental, os processos criativos para a cena apostam no curto-circuito dos elementos e das convenções dramáticas, propondo novas possibilidades de construção cênica e novos tipos de narrativas. "A composição desloca-se, pois, do foco do drama para o plano da ação, não a dramática, mas a performativa" (Torres Neto 2016, p. 159). O teatro passa a ser visto como "um evento singular, multifacetado, multidisciplinar e interartístico" (Mota 2017, p. 35).

As ideias de teatro musical como dado característico da música de vanguarda (Mendes), uma maneira musical de pensar no teatro (Kagel) e invenção de relações entre música e cena (Aperghis) aproximam a composição musical dessas reflexões recentes sobre a dramaturgia em dois sentidos, sucessivamente. $O$ primeiro sentido é o da aplicação de critérios e procedimentos composicionais musicais às materialidades cênicas. ${ }^{31}$ As ações são organizadas e dispostas a partir de um pensamento voltado para os recortes no tempo, para a escolha de sons e silêncios pelo critério da expressividade e para a construção de um senso de coerência e direção. As escolhas composicionais visam à costura gradativa do percurso sonoro, indissociável nesse tipo de abordagem criativa, da roteirização da performance a ser colocada sobre o palco na situação concreta de realização da peça. O segundo sentido é o da admissão do potencial mimético (representacional) das materialidades sonoras e gestuais/visuais com as quais se compõem e do estabelecimento de dispositivos para que jogos de construção e deslizamento de sentidos se realizem na performance.

No trabalho composicional, a manutenção desse tipo de relação, e seu desenvolvimento ao longo de cada peça específica, implica na busca do equilíbrio entre duas demandas. De um lado, a invenção e organização das ações com ou sem resultantes sonoras. De outro lado, a marcha de possíveis sentidos de representação cênica implicados nessas mesmas ações. No teatro musical pós1960, essas demandas e, consequentemente, as funções de composição e

\footnotetext{
${ }^{31}$ Sentido esse análogo aos postulados de Kagel (por exemplo, apud Bosseur 1971) e à moldura teórica dos pesquisadores proponentes da noção de Teatro Composto (Rebstock 2012; Roesner 2012).
} 
OLIVEIRA, H. M. Espaço, materiais e forma no teatro musical pós-1960: composição e dramaturgia em obras de Mendes, Kagel e Aperghis

dramaturgia - organização de estruturas musicais e eventos cênicos - se integram e se sobrepõem.

\section{Referências}

1. Aperghis, Georges. Graffitis (1980). 2014. [Vídeo] Alexander Wnuk, percussão. Copenhagen: Royal Danish Academy of Music. URL: <https://youtu.be/UUj0knMsA78>, acesso em maio de 2019.

2. 7 crimes de l'Amour. 1979. [Vídeo] Sarah Maria Sun, soprano; Sebastian Wendt, clarinete; Stephan Meier, percussão. Hannover: Musik 21 Niedersachsen, 2013a. URL: <https://youtu.be/aZ48kO LiRs>, acesso em maio de 2019.

3 . Retrouvailles. 2013. [Partitura] Paris: Didascalia, 2013c. URL: $<$ https://drive.google.com/file/d/0B4bDGe8g1UPhQkZRSTE3cFFYS2M/view $>$, acesso em maio de 2019 .

4. Retrouvailles. 2013. [Vídeo] Richard Dubelski e Christian

Dierstein. Witten: Wittener Tage für neue Kammermusik Festival, 2013d. URL: < https://youtu.be/0-3LFmAf DM>, acesso em maio de 2019.

5. Graffitis. 1980. [Vídeo] Juanjo Llopico, percussão. Onda (Espanha), 2013e. URL: <https://youtu.be/UUYlt7v6S00>, acesso em maio de 2019.

6. Les guetteurs des sons. 1981. [Vídeo] Agnieszka KoprowskaBorn, Louisa Marxen e Yuriko Sekiguchi. Basel: Mimiko, 2011a. URL: $<$ https://youtu.be/7ly1VuBMQuk>, acesso em maio de 2019.

7. Luna Park. 2011. [Vídeo]. Eva Furrer (flauta, Octabase and voice), Johanne Saunier (voice and danse), Mike Schmidt (base flute and voice), and Richard Dubelsky (air percussion and voice). Paris: IRCAM, 2011b. URL: <https://youtu.be/biTGIRROgZA >, acesso em maio de 2019.

8. . 7 crimes de l'Amour. 1979. [Partitura] Paris: Didascalia, 2006a. URL: <https://drive.google.com/file/d/0B4bDGe8g1UPhSTg3d DE0bmhQbVU/view $>$, acesso em maio de 2019.

9 . Le corps à corps. 1978. [Partitura] Edição do autor, 2006b. URL: $\quad<$ https://drive.google.com/file/d/0B4bDGe8g1UPhZDBmMV

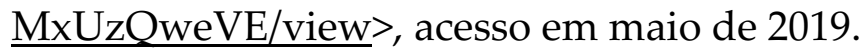

10. Les guetteurs des sons. 1981. [Partitura] Edição do autor,

2006c. URL: $\leq$ https://drive.google.com/file/d/0B4bDGe8g

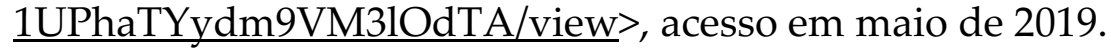


MUSICA THEORICA Revista da Associação Brasileira de Teoria e Análise Musical 2019, v. 4, n. 1, p. 124-159-Journal of the Brazilian Society for Music Theory

11. Le corps à corps. 1978. [Vídeo] Françoise Rivalland. Paris: POLediteur, 2004. URL: <https://youtu.be/M1ONFZ042fc>, acesso em maio de 2019.

12. Graffitis. 1980. [Partitura] Paris: Salabert, 1980.

13. Bithell, David. Experimental music theater. In: Grove Music Online. Oxford Music Online. URL: <http://www.oxfordmusiconline.com/subscriber/ article/grove/music/A2240884>, acesso em novembro de 2017. Oxford University Press, 2016.

14. Bosseur, Dominique; Bosseur, Jean-Yves. 1990. Revoluções musicais: a música contemporânea depois de 1945. Lisboa: Editorial Caminho.

15. Bosseur, Jean-Yves. Entretien avec Mauricio Kagel. 1971. Musique en jeu, 5, França, nov., p. 99-106.

16. Carrasco, Ney. 2005. A infância muda: a música nos primórdios do cinema. ouvirOUver, Uberlândia, n. 1, p. 35-45. URL: <http://www.seer.ufu.br/ index.php/ouvirouver/article/view/24/38>, acesso em maio de 2019.

17. Chion, Michel. 2011. A Audiovisão: som e imagem no cinema. Portugal: Texto e Grafia.

18. Danan, J. 2010. Mutações da dramaturgia: tentativa de enquadramento (ou de desquadramento). MORINGA - Artes do Espetáculo, v. 1, n. 1, p. 117-123.

19. Donin, Nicolas; Trubert, Jean-François. 2010. Georges Aperghis - Noyaux, matrices, oignons (...et corbeille). Genesis, 31, p. 65-76.

20. Dos Santos, Kemuel Kesley Ferreira; Chaib, Fernando Martins de Castro; De Morais, Ronan Gil; De Oliveira, Fabio Fonseca. 2015. Processo de adaptação de uma tradução de texto como parte da preparação interpretativa da obra cênico musical Graffitis de Georges Aperghis. In: Seminário Nacional de Pesquisa em Música da UFG, XV, Anais..., pp. 99-109.

21. Féral, Josette. 2015. Além dos limites: teoria e prática do teatro. São Paulo: Perspectiva.

22. Kagel, Mauricio. MM51. 1976. [Vídeo] Klaus Steffes-Holländer, piano. Freiburg: Ensemble Recherche, 2017. URL: <https://youtu.be/ usdBER8zUZU>, acesso em maio de 2019.

23. MM51. 1976. [Vídeo]. Aloys Kontarsky, piano; Mauricio Kagel, direção. Zurique: Schweizer Fernsehens DRS, 1983. Disponível em: <https:/youtu.be/Gu-fLh2sGT0>, acesso em maio de 2019.

24. . MM51. 1977. [Partitura] Londres: Universal Edition. 
OLIVEIRA, H. M. Espaço, materiais e forma no teatro musical pós-1960: composição e dramaturgia em obras de Mendes, Kagel e Aperghis

25. Mendes, Gilberto. Santos Football Music. 1969. [Vídeo] In: A Odisseia Musical de Gilberto Mendes [DVD]. São Paulo: Berço Esplêndido, 2005a. Disponível em $<$ https://youtu.be/V3bmKryl-cI >, acesso em maio de 2019.

26.

Beba Coca-Cola. 1966. [Vídeo] Coro da OSESP; Naomi Munakata, regência. In: A odisseia musical de Gilberto Mendes [DVD]. São Paulo: Berço Esplêndido, 2005b. Disponível em <https://youtu.be/6DKRtGjIaD4>, acesso em maio de 2019.

27. 1994. Uma odisséia musical: dos mares do sul à elegância pop/art déco. São Paulo: Editora da Universidade de São Paulo, Editora Giordano.

28. Santos Football Music. 1979. [Partitura] Brasília: Sistrum.

29. Mota, Marcus. 2017. Dramaturgia: conceitos, exercícios e análises. Brasília: Editora UnB.

30. Oliveira, Heitor Martins. 2018. Música-como-teatro: uma prática composicional e sua autoanálise. Tese (Doutorado em Música) - Instituto de Artes, Universidade Federal do Rio Grande do Sul. Porto Alegre.

31. 2016. Composição musical e teatralidade em Speaking Drums, de Péter Eötvös. Dramaturgias - Revista do Laboratório de Dramaturgia - LADI - UnB, v. 2/3, p. 58-71. URL: <http://periodicos.unb.br 〈index.php/dramaturgias/article/view/21895>, acesso em junho de 2017.

32. 2015. Música e teatralidade: a perspectiva composicional. Debates (Unirio), n. 15, p. 49-66.

33. Rebstock, Matthias. 2012. Composed Theatre: mapping the field. In: Rebstock, Matthias; Roesner, David. Composed Theatre: aesthetics, practices, processes. Kindle Edition. Bristol, UK / Chicago, USA: Intellect, Chapter 1.

34. Roesner, David. 2012. Introduction: Composed Theatre in context. In: Rebstock, Matthias; Roesner, David. Composed Theatre: aesthetics, practices, processes. Kindle Edition. Bristol, UK / Chicago, USA: Intellect.

35. Salzman, Eric; Dési, Thomas. 2008. The New Music Theater: seeing the voice, hearing the body. Kindle Edition. New York: Oxford University Press.

36. Sarrazac, Jean-Pierre. 2009. A invenção da teatralidade. Apresentação e tradução: Alexandra Moreira da Silva. Senhora da Hora: Deriva Editores.

37. Serale, Daniel Osvaldo. 2009. Música, teatro, música-teatro e percussão na música-teatro. Cadernos do Colóquio, v. 10, n. 1, p. 210-221.

38. Torres Neto, Walter Lima. 2016. O termo dramaturgia hoje. In: Ensaios de cultura teatral. Jundiaí-SP: Paco Editorial, p. 149-164. 
MUSICA THEORICA Revista da Associação Brasileira de Teoria e Análise Musical 2019, v. 4, n. 1, p. 124-159-Journal of the Brazilian Society for Music Theory

39. Trubert, Jean-François. 2015. Théâtre musical et théâtre instrumental. In: Donin, Nicolas; Feneyrou, Laurent. Théories de la composition musicale au XXe siècle volume 2. Lyon: Symétrie, p. 1269-1295. 